\title{
ГЕОХІМІЧНІ ОСОБЛИВОСТІ \\ СІРЧАНОКИСЛИХ ЛАНДШАФТІВ
}

\author{
Зубова Л. Г., Зубов О. Р., Зубов А. О.
}

\section{ВСТУП}

У степу, у т. ч. на території Донецького вугільного басейну (Донбасу), природними ландшафтами $є$ кальцієві. Водночас на значній частині басейну спостерігаються антропогенні сірчанокислі ландшафти. Які ж причини зумовили це явище? У 20-х pp. XVIII ст. на Донбасі було розвідане кам'яне вугілля, а в 1795 р. почався його систематичний видобуток. За два століття з моменту появи перших шахт територія Донбасу помітно змінилася. Відбулася докорінна зміна природних ландшафтів. Значна частина природних кальцієвих ландшафтів вкрилася териконами - відвалами вугільних шахт висотою до 100 м, із кутами відкосів до $40^{\circ}$ і площею основи до десятків гектарів - і перетворилися у сірчанокислі. Пірит, який при розтині пласта потрапляє разом із відвальною породою на поверхню, вступає у реакцію 3 киснем повітря та сприяє утворенню сірчанокислого класу підземних і поверхневих вод, грунтів, кори вивітрювання, тобто відбувається трансформація природних кальцієвих ландшафтів в антропогенні сірчанокислі (рис. 1).

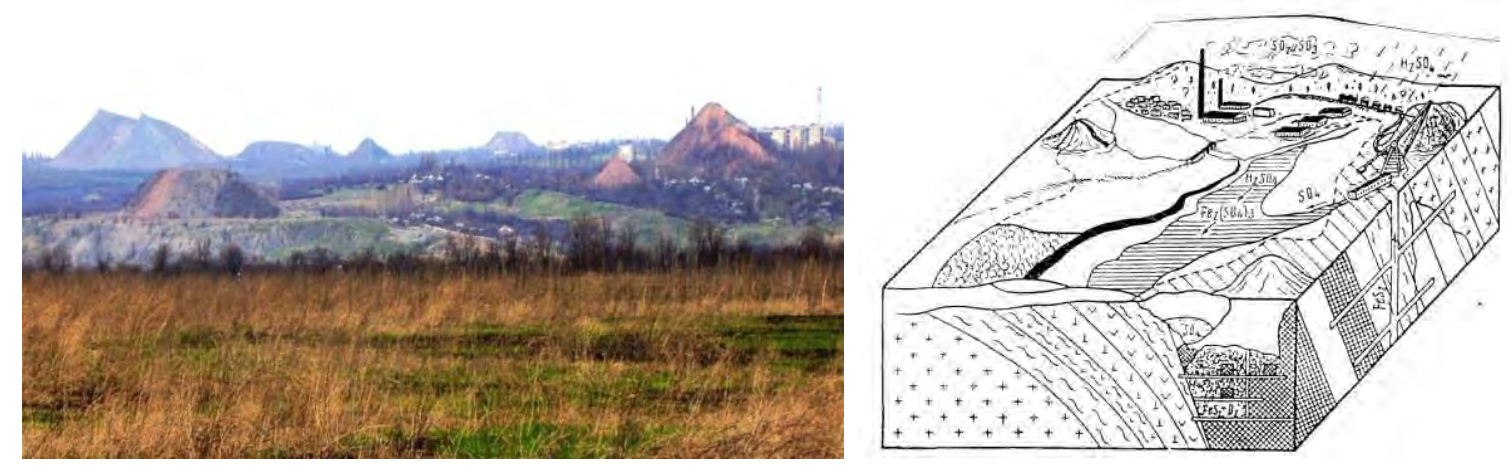

Рис. 1. Загальні вид і схема ${ }^{1}$ (за В.Г. Прохоровим) сірчанокислого ландшафту

Природні ж сірчанокислі ландшафти виникають у місцях виходу на поверхню сульфідних руд, у т. ч. у вулканічних районах (рис. 2).

\footnotetext{
${ }^{1}$ Перельман А.И. Биокосные системы Земли. Москва : Наука, 1977. 160 с.
} 

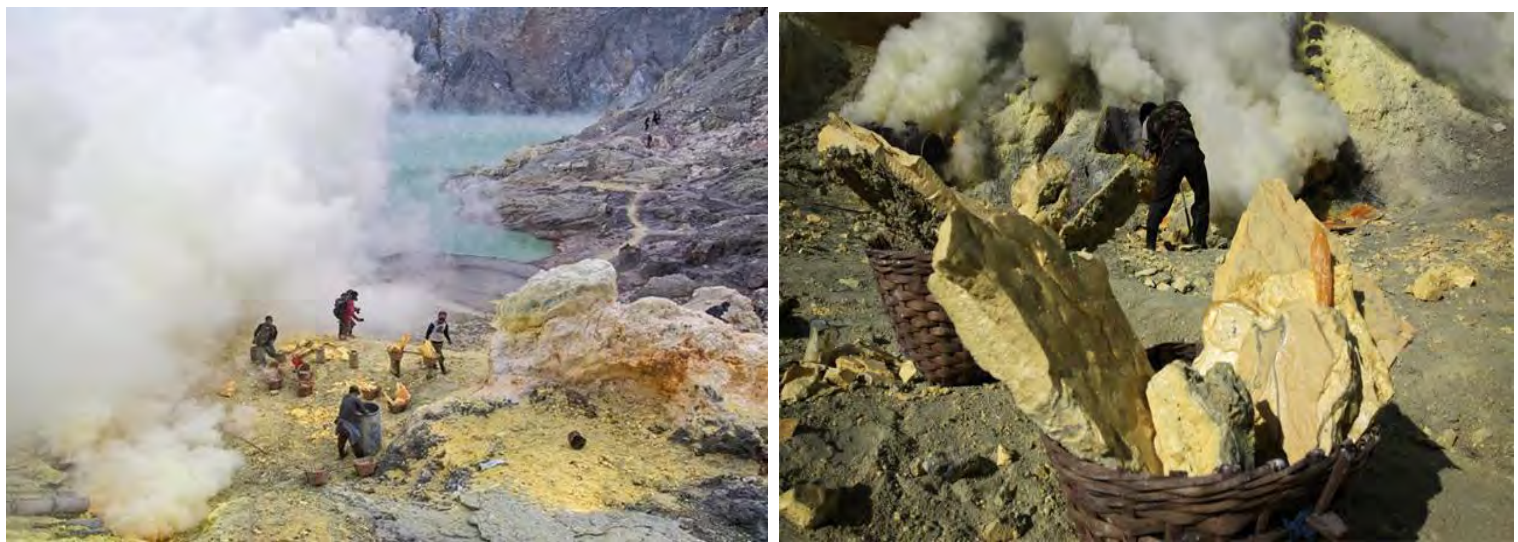

Рис. 2. Озеро у кратері вулкана Кава Іджен (о. Ява) з місцями виходу сірки по берегах, ïi збір і транспортування (//cont.ws/@sonikx/819530)

За умов сірчанокислих ландшафтів формується сірчанокислий клас кори вивітрювання, грунтів, поверхневих і підземних вод із низьким (менше 3) значенням $\mathrm{pH}^{1}$. Нижче представлені глобальні наслідки діяльності сірчанокислих ландшафтів.

\section{1. Зв'язок «Тихоокеанського вогняного кільця» острівних вулканів із антициклонами Північної півкулі Землі}

Взаємодія атмосфери, літосфери та гідросфери у зимовий період. Як показано у табл. 1, у Північній півкулі антициклони весь зимовий період знаходяться переважно над континентами: Північною Америкою; Азією (з центром над Монголією, Якутією, Магаданською обл.); Східною Європою (Балканами); Північчю Африки ${ }^{2,3}$, грунтовий покрив яких покритий снігом, проте на значній території у періоди коротких відлиг (1-3, іноді 4 рази за зиму) завдяки його таненню та передачі тепла талої води мерзлим шарам грунтів останні піддаються розрідженню. Відбувається термічна абразія льодистих грунтів, що мали до промерзання пухку структуру, та їх відтавання. За підвищеного атмосферного тиску, притаманного антициклонам, зростає розчинність газів. У талій сніговій воді розчиняється більша кількість вуглекислого газу.

Вміст $\mathrm{CO}_{2}$ у талих водах визначається парціальним тиском $\mathrm{CO}_{2}$ в атмосфері над розчином $\mathrm{pCO}_{2}$ розтопленого снігу. Розчинність $\mathrm{CO}_{2}$ у талій воді завдяки наявності у степу, лісостепу вапняків $\mathrm{i}$ обвапнякованої кори вивітрювання різко підвищується внаслідок утворення розчинного у воді гідрокарбонату (бікарбонату) кальцію:

\footnotetext{
${ }^{2}$ Хромов С.П., Петросянц М.А. Метеорология и климатология : учебник. Москва : Изд-во МГУ, 2001. $528 \mathrm{c}$.

3 Гончарова Л.Д., Серга Е.М., Школьний Є.П. Клімат і загальна циркуляція атмосфери : навчальний посібник. Київ : КНТ, 2005. 251 с.
} 
$\mathrm{CaCO}_{3}+\mathrm{H}_{2} \mathrm{O}+\mathrm{CO}_{2}=\mathrm{Ca}\left(\mathrm{HCO}_{3}\right)_{2}$, тобто в зимовий період має місце більш високий стік $\mathrm{CO}_{2}$ у грунт. Загальновідомо, що за присутності $\mathrm{CO}_{2}$ розчинність карбонату кальцію різко збільшується внаслідок утворення розчинного у воді гідрокарбонату кальцію, який існує тільки в талих водних розчинах. Це триває кілька днів - у періоди відлиг. Після замерзання води $\mathrm{Ca}\left(\mathrm{HCO}_{3}\right)_{2}$ розпадається 3 виділенням $\mathrm{CO}_{2}$ й утворенням нерозчинного карбонату кальцію.

А.І. Перельман стверджував, що всі степи та пустелі належать до однієї зони кори вивітрювання, хоча на цій території містяться чотири грунтові зони. Тому на вивержених породах - і під чорноземним, і під каштановим, і під сіроземним грунтами - створюється одна й та сама кора вивітрювання, уламкова «обызвесткованная» ${ }^{1}$. Відповідно, наявність i динаміка карбонату кальцію в цих грунтах зумовлені тисячолітньою взаємодією атмосфери 3 літосферою та присутністю зимових антициклонів над континентами зі сніговим покривом $\mathrm{i}$ підвищеним вмістом $\mathrm{CO}_{2}$.

Взаємодія атмосфери, літосфери, гідросфери в літній період. У цю пору антициклони Північної півкулі знаходяться переважно над Тихим $\mathrm{i}$ Атлантичним океанами (табл. 1) ${ }^{2,3}$. Повітряне середовище над Тихим океаном із масштабними літніми антициклонами оточене т. зв. «Тихоокеанським вогняним кільцем» (рис. 3) із природними сірчанокислими ландшафтами острівних вулканів і розділюється екватором на північну і південну частини. Тут зосереджена переважна частина усіх активних вулканів Землі, яких, за різними підрахунками, налічується від 1000 до $1500^{4}$. Вони є джерелом надходження в атмосферу тепла, водяної пари та багатьох газів.

Відомо, що у субтропічних антициклонах на висоті майже 1000 м існують т. зв. затримуючі шари атмосфери, під якими накопичується волога, що випаровується 3 поверхні океанів. Згідно $3^{5}$ ці шари - головні акумулятори атмосферної вологи на Земній кулі.

У східній приекваторіальній частини Тихого океану відбуваються Ель-Ніньо (ЕН) - позитивні аномалії температури води. Завдяки дальнодії це один із найважливіших процесів у глобальній кліматичній системі, що відповідають за формування погодно-кліматичних аномалій на Землі..

3 Ель-Ніньо-Південним коливанням (ЕНЮК) пов'язана валкеровська циркуляція - особлива коливальна структура в системі «океан атмосфера».

\footnotetext{
${ }^{4}$ Вулканы и вулканология. URL: http://geo.web.ru/db/volcano/active_volcano.html.

${ }^{5}$ Рощин А.Н. Сам себе синоптик. Київ : Рад. школа, 1983. 206 с.

${ }^{6}$ Лубков А.С., Воскресенская Е.Н., Марчукова О.В. Пространственно-временная классификация явлений Эль-Ниньо. Матер. конф. «Окружающая среда и человек». Ростов-на-Дону : Изд-во ЮНЦ PAH, 2016. C. 110-112.
} 
Таблиця 1

Найбільш характерне розташування антициклонів за сезонами ${ }^{7,8}$

\begin{tabular}{|c|c|}
\hline Літо (липень) & Зима (січень) \\
\hline \multicolumn{2}{|c|}{ Північна півкуля } \\
\hline $\begin{array}{l}\text { 1. Атлантичний океан } \\
\text { (Азорський) }\end{array}$ & $\begin{array}{l}\text { 1. Північна Америка (Канадський, } \\
1020 \text { гПа) }\end{array}$ \\
\hline $\begin{array}{l}\text { 2. Тихий океан (Гавайський } \\
\text { або Гонолульський, } \\
1020 \text { гПа) }\end{array}$ & $\begin{array}{l}\text { 2. Азія (Азіатський (Сибірський), } \\
1035 \text { гПа із центром над Монголією, } \\
\text { Якутією, Магаданською обл. }\end{array}$ \\
\hline 3. Середземне море & 3. Східна Свропа, Балкани \\
\hline $\begin{array}{l}\text { 4. Моря Арктичного } \\
\text { басейну }\end{array}$ & 4. Північ Африки \\
\hline
\end{tabular}

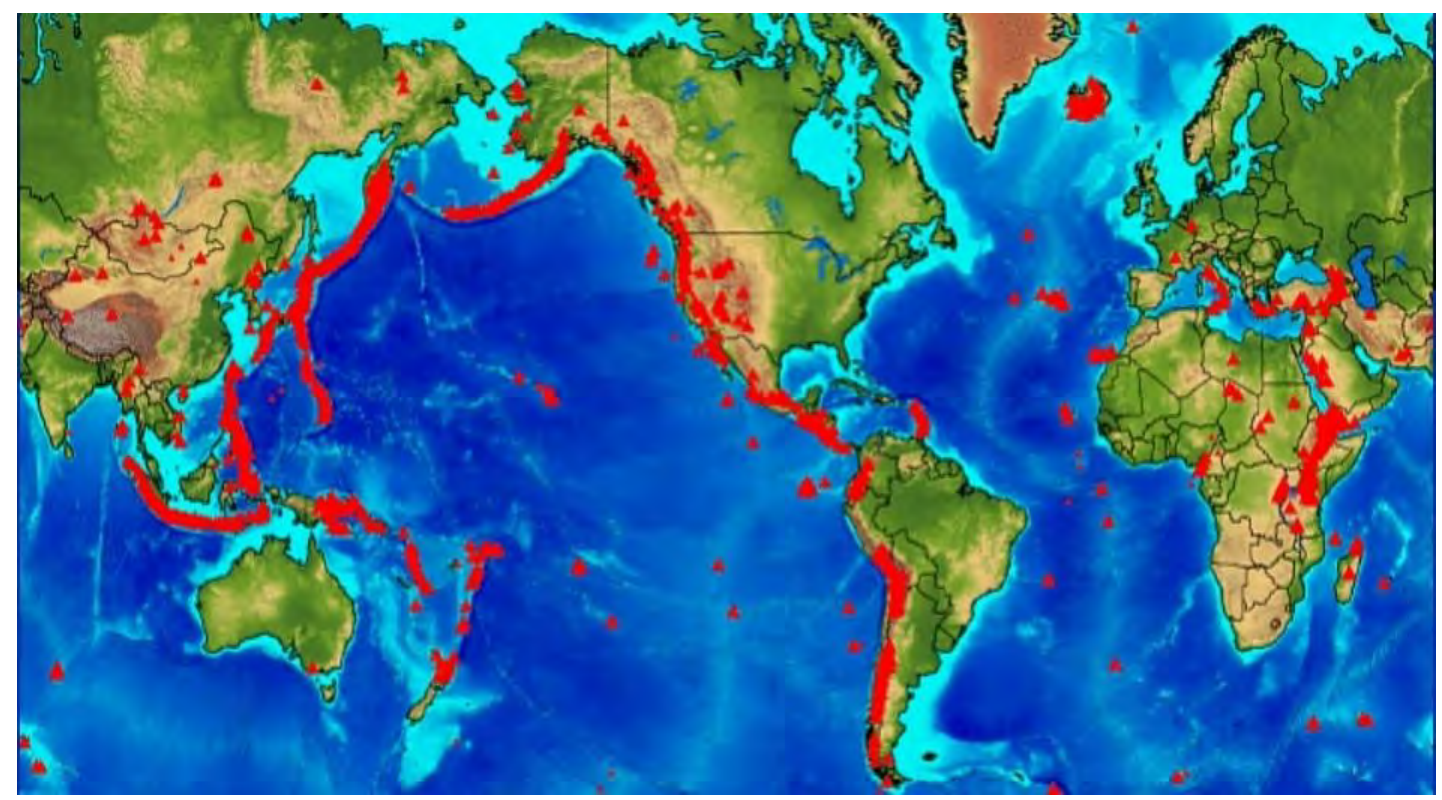

Рис. 3. «Тихоокеанське вогняне кільце» ${ }^{9}$

Валкерівська ділянка $є$ зональною циркуляцією в екваторіальній області, керованою температурним градієнтом океану. Повітряні маси південно-східного пасату над Тихим океаном переміщаються з більш холодних східних акваторій океану в західному напрямку, де вони прогріваються, збагачуються вологою, піднімаються вгору в області екваторіальної улоговини та переносяться у протилежному напрямку.

\footnotetext{
${ }^{7}$ Хромов С.П., Петросянц М.А. Метеорология и климатология : учебник. Москва : Изд-во МГУ, 2001. 528 c.

8 Гончарова Л.Д., Серга Е.М., Школьний Є.П. Клімат і загальна циркуляція атмосфери : навчальний посібник. Київ : КНТ, 2005. 251 с.

${ }^{9}$ Инфоурок. URL: https://fs00.infourok.ru/images/doc/225/29589/1/img4.jpg.
} 
Циркуляція Валкера безпосередньо пов'язана із т. Зв. Південним коливанням $(Ю К)^{2}$. Сигнал ЕНЮК передається із тропіків Тихого океану в Північну Атлантику по «атмосферному мосту», ланками якого $є$ хвилі Россбі, струменеві течії у тропосфері та циклони. У такий спосіб теплі (Ель-Ніньо) і холодні (Ла-Нінья) події можуть впливати на центри дії атмосфери Північної Атлантики, які впливають на гідрометеорологічні характеристики на території Свропи ${ }^{10}$.

Теоретичне порівняння антициклональних природних процесів, що відбуваються у північній півкулі Землі, 3 етапами промислового отримання з водяної пари т. зв. «водяного газу» - Watergas (Wassergas) наводить на думку про їхню деяку аналогію (табл. 2). Оксид вуглецю СО (чадний газ), який міститься у водяному газі на 41,2\%, $\epsilon$ дуже небезпечним для життя людини, приводячи до проявів, аналогічних крайнім ознаками Covid-19. Це дозволяє припустити, що безсніжна зима 2019-2020 pp., коли відтік $\mathrm{CO}$, як і $\mathrm{CO}_{2}$, у грунти був ускладнений, сприяла тяжкості протікання цього захворювання.

Розташування зимових антициклонів Північної півкулі над континентами, наявність снігового покриву, присутність карбонату кальцію в ілювіальному горизонті грунтів пов'язані між собою. Антициклональна діяльність у Північній півкулі Землі теоретично аналогічна етапам отримання Watergas i гіпотетично може істотно впливати на здоров’я населення Землі.

Таблиця 2

\section{Порівняння природних процесів з етапами отримання Watergas}

\begin{tabular}{|c|c|}
\hline Природні процеси & Етапи отримання Watergas \\
\hline $\begin{array}{l}\text { 1. У «Тихоокеанському } \\
\text { вогняному кільці» з численними } \\
\text { активними острівними } \\
\text { вулканами атмосферне повітря, } \\
\text { збагачене } \mathrm{CO}_{2} \text { (внаслідок дії } \\
\text { підвищеного атмосферного } \\
\text { тиску при антициклонах), } \\
\text { сильно прогрівається } 3 \\
\text { подальшим утворенням } \\
\text { повітряної суміші, яка є } \\
\text { природним аналогом } \\
\text { генераторного газу. }\end{array}$ & $\begin{array}{l}\text { У шахтну конусоподібну } \\
\text { вертикальну піч (генератор) із } \\
\text { вогнетривкого каменю для } \\
\text { посиленого горіння коксу або } \\
\text { антрациту знизу під великим } \\
\text { тиском (до } 440 \text { мм) вдувають } \\
\text { повітря. Цей процес називається } \\
\text { Warmblasen - гаряче дуття. } \\
\text { Результатом є утворення } \\
\text { генераторного газу, що складається } \\
\text { на } 68 \% \text { iз } \mathrm{N}_{2}, 28 \% \text { - із СО, на } 2 \%-3 \\
\mathrm{CO}_{2} \text { і } 2 \%-3 \mathrm{H}_{2} \text {. } \\
\text { Процес припиняєтья. }\end{array}$ \\
\hline
\end{tabular}

10 Маслова В.Н. Циклоническая активность в Черноморско-Средиземно-морском регионе : автореф. дис. ... канд. геогр. наук : 11.00.09. Севастополь, 2012. 20 с. 
Закінчення табл. 2

\begin{tabular}{|l|l|}
\hline Внаслідок ендотермічної реакції & Водяну пару пропускають через \\
водяної пари та розпеченого & розпечений до $1000-1200^{\circ} \mathrm{C}$ \\
вулканічного вуглецю & горючий матеріал. Для підтримки \\
утворюється водяний газ - & температури час від часу \\
суміш водню й оксиду вуглецю: & пропускають повітря або \\
$\mathrm{H}_{2} \mathrm{O}+\mathrm{C}+132$ кДж / моль $\rightarrow \mathrm{H}_{2}$ & насичують нею пару. Процес має \\
$+\mathrm{CO}$ & назву холодне дуття (Кaltblasen). \\
& Його результатом є утворення \\
& водяного газу $\left(\mathrm{H}_{2} \mathrm{O}+\mathrm{C} \rightarrow \mathrm{CO}+\right.$ \\
& $\left.\mathrm{H}_{2}\right)$. Склад газу: $\mathrm{CO}_{2}-4 \%, \mathrm{CO}-$ \\
& $41,2 \%, \mathrm{H}_{2}-49,5 \%, \mathrm{~N}_{2}-5,3 \%$ \\
\hline У східній приекваторіальній & Зовні, на нижній частині, що \\
частини Тихого океану в межах & нагрівається, генератор має \\
«Тихоокеанського вогняного & охолоджуюче кільце, стінки якого \\
кільця» спостерігаються Ель- & омиваються холодною водою, що \\
Ніньо - позитивні аномалії & постійно притікає. \\
температури води. & \\
\hline
\end{tabular}

\section{2. Глобальні катастрофічні явища у вугледобувній промисловості різних країн}

Володимир Іванович Вернадський назвав людство потужною геологічною силою, яка змінює світ. I саме він «розвинув концепцію ноосфери як зростаючого глобального усвідомлення вторгнення людини у природні біогеохімічні цикли» ${ }^{11}$.

Метою цього підрозділу є розгляд глобальних катастрофічних явищ у вугледобувній промисловості різних країн. Для досягнення поставленої мети були вирішені такі завдання: 1) проаналізувати збіг місць падіння метеоритів із розташуванням розроблюваних родовищ вугілля; 2) вивчити основні геохімічні фактори, що сприяють виникненню «псевдометеоритів»; 3) дослідити наслідки ядерного ділення торію при окисленні сульфідів у вапняках.

При вивченні збігу місць падіння метеоритів із розташуванням родовищ вугілля Канади встановлено, що вугільні родовища зосереджені переважно у тї східних і західних провінціях. Місцезнаходження вугледобувних провінцій і територій ілюструється pис. 4 (https://ru.wikipedia.org/), де вони показані відтінками зеленого кольору (Британська Колумбія, Альберта, Саскачеван) за винятком Манітоби, червоним (Нова Шотландія) і рожевим (Нью-Брансуік).

\footnotetext{
${ }^{11}$ Горелов А.А. Концепции современного естествознания : учебное пособие. Москва : ООО «Издательство АСТ», 2003. 380 с. 


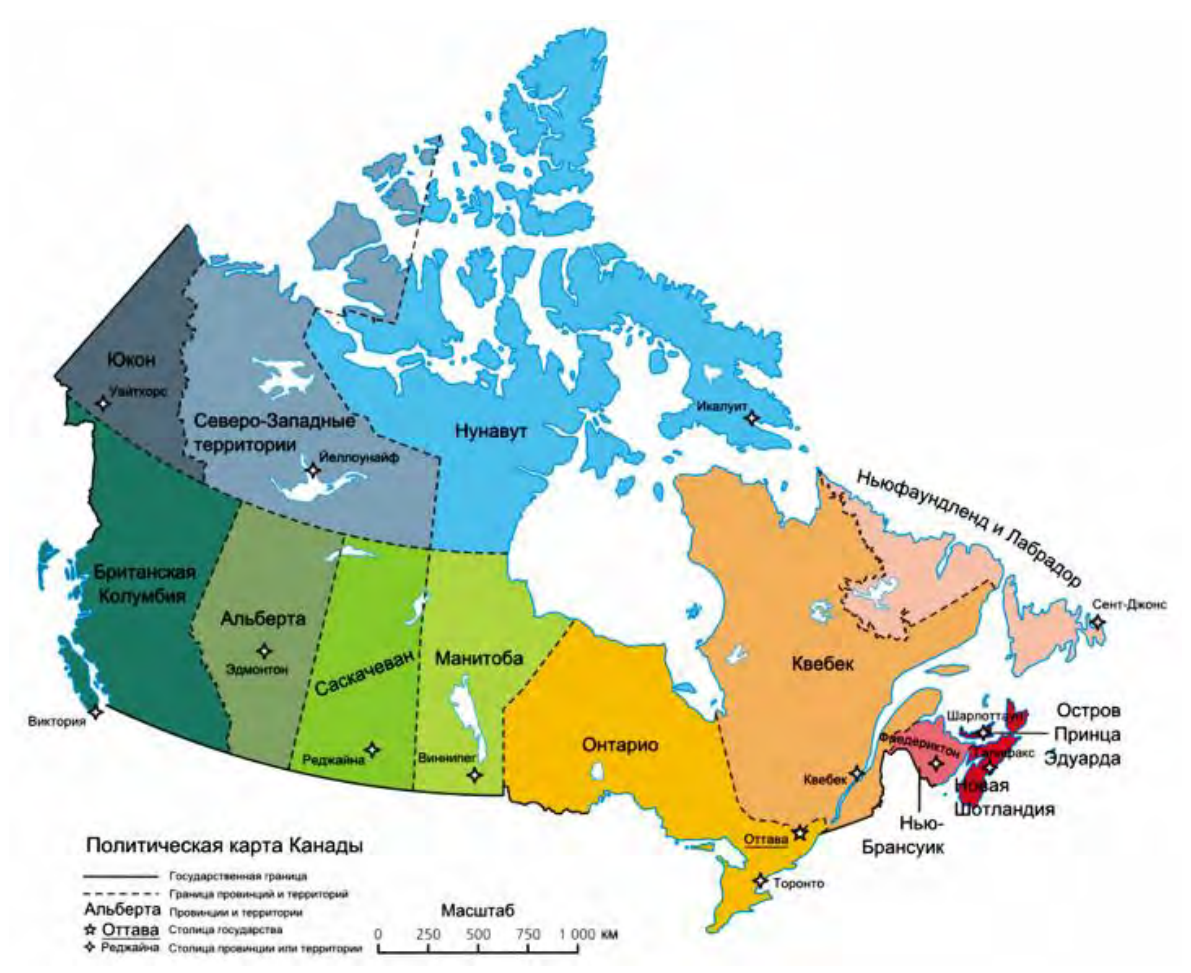

Рис. 4. Адміністративний поділ Канади на провінції та території

У табл. 3 представлені знайдені в інтернеті описи метеоритів, які спостерігалися у Канаді з 1931 по 2017 рр. Як можна побачити, усі згадані в ній метеорити спостерігалися у тих самих 4 провінціях, де проводиться вуглевидобуток.

Таблиця 3

Дати та місця падіння метеоритів у Канаді

\begin{tabular}{|c|l|}
\hline Дата падіння метеорита & \multicolumn{1}{|c|}{ Місце падіння метеорита і його назва } \\
\hline 1931 p. & Саскачеван, Springwater \\
\hline 1952 p. & Альберта, Abbe \\
\hline 1960 p. & Альберта, Bruderheim \\
\hline 1963 p. & Альберта, Peace River \\
\hline 18.01 .2000 p. & Британська Колумбія (Юкон) \\
\hline 2008 p. & Альберта, Buzzard Coulee \\
\hline 22.11 .2008 p. & Альберта, Саскачеван (Ллойдминстер) \\
\hline 22.02 .2012 p. & Саскачеван (Норт Беттлфорд) \\
\hline 18.03 .2014 р. & Нью-Брансуік, о. Принца Едуарда \\
\hline 5.09 .2017 р. & $\begin{array}{l}\text { Альберта, Британська Колумбія (Келоуїн, } \\
\text { Калгарі) }\end{array}$ \\
\hline 24.11 .2017 р. & Саскачеван, Альберта \\
\hline
\end{tabular}


Такі ж боліди спостерігалися в Росії: в Тунгуському вугільному басейні у 1908 р.; в Бодайбо-Балахіно (Пермський вугільний басейн) у 2002 р. та ін. Численні падаючі «псевдометеорити» спостерігаються і на територіях багатьох вугільних басейнів Америки.

Процес вибуху болідів у вугільних басейнах визначається, на нашу думку, наявністю трьох основних чинників (компонентів): сульфідів, вапняків і елемента торія. Прояв взаємодії сульфідів і вапняків показано при характеристиці умов утворення геохімічних бар'єрів.

У табл. 4 представлена характеристика умов утворення основних геохімічних бар'єрів, на яких концентруються рідкоземельні елементи.

Таблиця 4

Характеристика умов утворення основних геохімічних бар'єрів, на яких концентруються рідкоземельні елементи (за А.І. Перельманом ${ }^{12}$ )

\begin{tabular}{|c|c|}
\hline $\begin{array}{l}\text { Класи геохімічних } \\
\text { бар'єрів і аномалій }\end{array}$ & Умови виникнення \\
\hline $\begin{array}{l}Д_{1-}-\text { лужний (виникає у } \\
\text { місцях підвищення } \\
\text { рН середовища) }\end{array}$ & $\begin{array}{l}\text { Формується при окисленні сульфідних руд, } \\
\text { що залягають у вапняках. Утворені } \\
\text { сірчанокислі розчини, які несуть різні } \\
\text { метали, взаємодіють із вміщуючими } \\
\text { карбонатними породами. Внаслідок } \\
\text { підвищення рН на лужному бар'єрі } \\
\text { осідають гідроксиди та карбонати металів. }\end{array}$ \\
\hline $\begin{array}{l}\underline{\mathrm{E}}_{3}-\text { - Кислий } \\
\text { (утворюється при } \\
\text { зменшенні рН, } \\
\text { особливо при зміні } \\
\text { лужного середовища на } \\
\text { кисле) }\end{array}$ & $\begin{array}{l}\text { Формуються в зоні окислення сульфідних } \\
\text { руд у вапняках, у яких можливий струм вод } \\
\text { у бік сульфідних руд. Гідрокарбонатні води } \\
\text { мають слаболужну реакцію і можуть } \\
\text { містити підвищені кількості кремнезему. } \\
\text { Останній буде осідати при зустрічі лужних } \\
\text { вод із кислими, тобто на кислому бар'єрі. } \\
\text { Як наслідок, відбувається окремінення } \\
\text { вапняків, характерне для зон окислення } \\
\text { сульфідних руд. }\end{array}$ \\
\hline $\begin{array}{l}\mathrm{G}_{1-}-\text { сорбційний } \\
\text { (виникає у місцях, де } \\
\text { води стикаються із } \\
\text { сорбентами) }\end{array}$ & $\begin{array}{l}\mathrm{G}_{1} \text { пов’язаний із концентрацією металів у } \\
\text { глинах, формується на ділянках окислення } \\
\text { сульфідних руд із характерними для них } \\
\text { сірчанокислими водами }\end{array}$ \\
\hline
\end{tabular}

\footnotetext{
12 Зубова Л.Г. Торий в природе и в сернокислых ландшафтах (научные факты и гипотезы) : монография. Луганск : Изд-во «Ноулидж», 2017. 72 с.
} 
Виходячи 3 даних табл. 4, рідкоземельні елементи в лужному i кислому геохімічних бар'єрах концентруються на ділянках окислення сульфідних руд, що залягають на вапняках. У мінералах, які вивітрюються і містять рідкоземельні елементи, останні дуже часто заміщені хімічним елементом торієм. Це пов'язано з подібними 3 ним хімічними властивостями елементів.

Торій, Th - радіоактивний хімічний елемент III групи періодичної системи Менделєєва, атомний номер 90, атомна маса 232,038, належить до актиноїдів, $\mathrm{t}$ плавлення $-1750^{\circ} \mathrm{C}, \mathrm{t}$ кипіння $-4200^{\circ} \mathrm{C}$, парамагнітний, температура переходу в надпровідний стан $1,4^{\circ} \mathrm{K}$, легко деформується на холоді. У більшості сполучень для торію характерна ступінь окислення +4 , але буває також $+2 \mathrm{i}+3$. Поширений у верхній частині літосфери із середнім вмістом $1,8 \cdot 10^{-3} \%{ }^{2}$.

Вищевказані фактори (сульфіди, вапняки та торій) досліджені на прикладі Донецького вугільного басейну. На рис. 5 показано вміст сульфідної сірки в одному 3 типових відвалів - відвалі шахти «Луганська» - та вид із космосу на териконовий сірчанокислий ландшафт ${ }^{13}$.
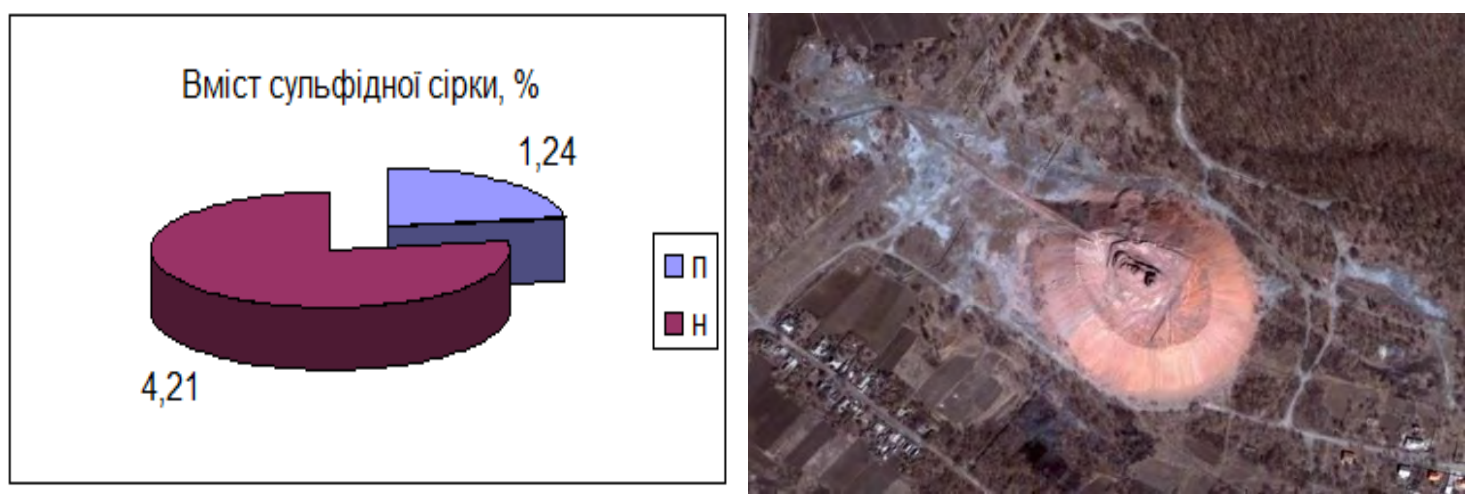

\section{Рис. 5. Вміст сульфідної сірки у перегорілій (п) і неперегорілій (н) породах і вид із космосу на териконовий сірчанокислий ландшафт Донбасу}

У складі світ карбону вугільних районів Луганської області (відповідно й у відвалах) вапняки займають від 0,4 до $17 \%$ (табл. 5$)^{14}$.

Дані 3 міцності вапняків у розрізі вугільних районів Луганської області ${ }^{12}$ представлено у табл. 6. Результати дослідження відвальних порід за допомогою спектрометричної установки «РИТМ-С» на предмет наявності торію представлено на рис. 6 і в табл. 7.

\footnotetext{
${ }^{13}$ Терриконы : монография / Л.Г. Зубова, А.Р. Зубов, А.А. Зубов и др. Луганск : Изд-во Ноулидж, 2015. 716 c.

${ }^{14}$ Смирный М.Ф., Зубова Л.Г., Зубов А.Р. Экологическая безопасность терриконовых ландшафтов Донбасса : монография. Луганск : Изд-во ВНУ им. В. Даля, 2006. 232 с.
} 
Таблиця 5

Кількісні показники присутності вапняків у складі світ карбону вугільних районів Луганської області ${ }^{15}$

\begin{tabular}{|c|c|c|c|c|}
\hline $\begin{array}{c}\text { Вугільні } \\
\text { райони }\end{array}$ & $\begin{array}{c}\text { Відділи кам’яно- } \\
\text { вугільних } \\
\text { відкладень, що } \\
\text { розробляються }\end{array}$ & $\begin{array}{c}\text { Світи та їхня } \\
\text { потужність, } \\
\text { м }\end{array}$ & $\begin{array}{c}\text { Вугілля, що } \\
\text { добувається, } \\
\text { та ступінь його } \\
\text { метаморфізму }\end{array}$ & $\begin{array}{c}\text { Вапняки, } \\
\%\end{array}$ \\
\hline \multirow{7}{*}{$\begin{array}{c}\text { Лиси- } \\
\text { чанський }\end{array}$} & \multirow{5}{*}{ середній } & $\mathrm{C}_{2}{ }^{3}-260$ & \multirow{7}{*}{ Д(1), трохи Г(П) } & 4,3 \\
\hline & & $\mathrm{C}_{2}{ }^{4}-250$ & & 3,5 \\
\hline & & $C_{2}^{5}-260$ & & 4,0 \\
\hline & & $\mathrm{C}_{2}{ }^{6}-140$ & & 4,8 \\
\hline & & $\mathrm{C}_{2}{ }^{7}-295$ & & 9,0 \\
\hline & \multirow{2}{*}{ верхній } & $\mathrm{C}_{3}{ }^{1}-375$ & & 4,5 \\
\hline & & $\mathrm{C}_{3}^{2}-275$ & & 3,2 \\
\hline \multirow{5}{*}{ Луганський } & \multirow{5}{*}{ середній } & $\mathrm{C}_{2}{ }^{3}-435$ & \multirow{5}{*}{$\begin{array}{c}\Gamma(\Pi), \text { Ж(Ш), К(1У), } \\
\text { Oc(У) }\end{array}$} & 1,5 \\
\hline & & $\mathrm{C}_{2}{ }^{4}-235$ & & 3,3 \\
\hline & & $\mathrm{C}_{2}{ }^{5}-400$ & & 5,2 \\
\hline & & $\mathrm{C}_{2}{ }^{6}-230$ & & 3,8 \\
\hline & & $\mathrm{C}_{2}{ }^{3}-450$ & & 9,0 \\
\hline \multirow{5}{*}{$\begin{array}{c}\text { Алмазно- } \\
\text { Мар'євський }\end{array}$} & \multirow{5}{*}{$\begin{array}{l}\text { верхній, } \\
\text { середній }\end{array}$} & $\mathrm{C}_{3}{ }^{1}-390$ & \multirow{5}{*}{$\begin{array}{c}\Gamma(\Pi), \\
\text { Ж(Ш) } \\
\text { К(1У), Oc(У) } \\
\text { Т(У1) }\end{array}$} & 4,1 \\
\hline & & $\mathrm{C}_{2}^{3}-500$ & & 1,1 \\
\hline & & $\mathrm{C}_{2}^{5}$ & & 3,6 \\
\hline & & $\mathrm{C}_{2}{ }^{6}$ & & $3,1-4,7$ \\
\hline & & $\mathrm{C}_{2}{ }^{7}$ & & 5 \\
\hline \multirow{5}{*}{$\begin{array}{l}\text { Красно- } \\
\text { донський }\end{array}$} & \multirow{5}{*}{ середній } & $\mathrm{C}_{2}^{3}-800$ & \multirow{5}{*}{$\begin{array}{c}\Gamma(\Pi), \\
Ж(\amalg) \\
\text { К(1У) } \\
\text { Oc(У) } \\
\text { Т(У1), ПА }\end{array}$} & 0,4 \\
\hline & & $\mathrm{C}_{2}^{4}-355$ & & 1,4 \\
\hline & & $\mathrm{C}_{2}{ }^{5}-570$ & & 5,6 \\
\hline & & $\mathrm{C}_{2}{ }^{6}-330$ & & 10,3 \\
\hline & & $\mathrm{C}_{2}{ }^{7}-440$ & & 17 \\
\hline \multirow{4}{*}{$\begin{array}{l}\text { Боково- } \\
\text { Хрусталь- } \\
\text { ський }\end{array}$} & \multirow{4}{*}{ середній } & $\mathrm{C}_{2}^{3}-875$ & \multirow{4}{*}{ А (УШ-Х) } & 0,5 \\
\hline & & $\mathrm{C}_{2}{ }^{4}-425$ & & 0,8 \\
\hline & & $\mathrm{C}_{2}^{5}-740$ & & 1,5 \\
\hline & & $\mathrm{C}_{2}^{6}-395$ & & 1,7 \\
\hline \multirow{5}{*}{$\begin{array}{l}\text { Должансько- } \\
\text { Ровенецький }\end{array}$} & \multirow{5}{*}{ середній } & $\mathrm{C}_{2}^{3}-1250$ & \multirow{5}{*}{ А (УШ-Х) } & 0,3 \\
\hline & & $\mathrm{C}_{2}{ }^{4}-450$ & & 1,6 \\
\hline & & $\mathrm{C}_{2}{ }^{5}-920$ & & 1,7 \\
\hline & & $\mathrm{C}_{2}{ }^{6}-500$ & & 2,1 \\
\hline & & $\mathrm{C}_{2}{ }^{7}-460$ & & 3,8 \\
\hline
\end{tabular}

${ }^{15}$ Там само. 
Таблиця 6

Міцність вапняків у розрізі вугільних районів, кг/см²

\begin{tabular}{|c|c|c|c|c|c|}
\hline \multicolumn{7}{|c|}{ Вугільні райони (стадії метаморфізму) } \\
\hline $\begin{array}{l}\text { Лисичан- } \\
\text { ський (1) }\end{array}$ & $\begin{array}{c}\text { Луганський } \\
\text { (П-У) }\end{array}$ & $\begin{array}{c}\text { Алмазно- } \\
\text { Мар'євський } \\
\text { (П-У1) }\end{array}$ & $\begin{array}{c}\text { Боково- } \\
\text { Хрустальський } \\
\text { (УШ-Х) }\end{array}$ & $\begin{array}{c}\text { Должансько- } \\
\text { Ровенецький } \\
\text { (УШ-Х) }\end{array}$ & $\begin{array}{c}\text { Краснодон- } \\
\text { ський (П-УП) }\end{array}$ \\
\hline $100-300$ & $300-600$ & $300-600$ & $300-600$ & $300-600$ & $300-600$ \\
\hline
\end{tabular}

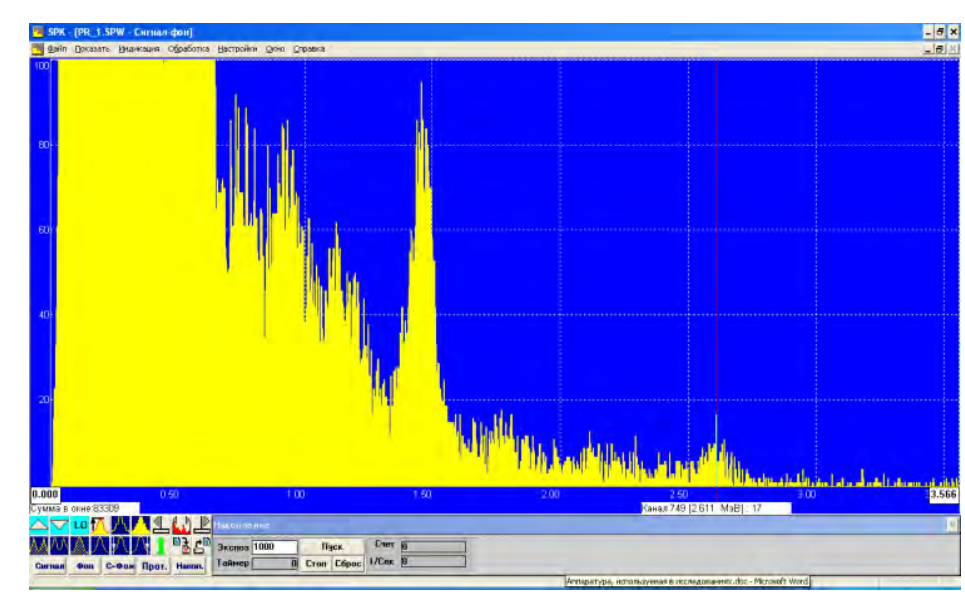

Рис. 6. Пік ${ }^{232}$ Th на спектрі

Таблиця 7

\section{Підтвердження присутності торію у спектрі гамма- випромінювання ${ }^{16}$}

\begin{tabular}{|c|c|c|c|c|c|}
\hline \multirow{2}{*}{ Нуклід } & \multicolumn{2}{|c|}{ Активність } & \multicolumn{1}{c|}{ Питома активність } & Похибка \\
\cline { 2 - 4 } & Бк & мкКи & Бк/кг & мкКи/кг & активності, \% \\
\hline \multicolumn{4}{|c|}{ Проби з відвалу шахти «Луганська» ПАТ «Луганськвугілля» } \\
\hline${ }^{232} \mathrm{Th}$ & 77,3 & 0,0021 & 64,4 & 0,0017 & 10,4 \\
\hline Проби з відвалу шахти ім. Ф.Д. Мельнікова ПАТ «Лисичанськвугілля \\
\hline${ }^{232} \mathrm{Th}$ & 63,8 & 0,0017 & 58 & 0,0016 & 15,2 \\
\hline
\end{tabular}

Процес «вскривання» торію відбувається таким чином. На ділянках, де $є$ сульфіди, відбувається їх окислення з утворенням сірчаної кислоти та перетворенням водних розчинів у сильнокислі $(\mathrm{pH}<3)$. Мінерали, що вміщують торій, трансформуються в сульфати. Згідно 3 А.І. Перельманом сірчанокислі розчини, які утворюються, що несуть метали (у т. ч. й торій), взаємодіють із вміщуючими карбонатними породами й усереднюються. Внаслідок підвищення рН на лужному бар'єрі осідають

\footnotetext{
16 Зубова Л.Г. Торий в природе и в сернокислых ландшафтах (научные факты и гипотезы) : монография. Луганск : Изд-во «Ноулидж», 2017. 72 с.
} 
гідроксиди та карбонати металів, наприклад: $\mathrm{Th}\left(\mathrm{SO}_{4}\right)_{2}+4 \mathrm{CaCO}_{3}=$ $=\mathrm{Ca}_{2}\left(\mathrm{Th}\left(\mathrm{CO}_{3}\right)_{4}\right)+2 \mathrm{CaSO}_{4}$.

Але чи завжди результатом взаємодії сульфату торію 3 вапняками (карбонатами) $є$ тверда фаза у вигляді гіпсу і карбонату торію? Проведені С.Г. Воробйовим під керівництвом Л.Г. Зубової досліди ${ }^{17}$ підтверджують, що деякі види вапняків можуть формувати геохімічний бар'єр Д до певних меж, а далі тверді опади при взаємодії сульфату торію з вапняками можуть не утворюватися, $\mathrm{pH}$ - майже не змінюватися. Розчин після взаємодії з такими вапняками залишається кислим.

Для моделювання лужних геохімічних бар'єрів Д при окисленні сульфідних руд, які залягають у вапняках, були використані два види карбонатної породи: з Білогорівського (Б) і Луганського (Л) кар'єрів. Визначено їхні властивості та склад (табл. 8, 9) $)^{18}$. Випробування проводилися відповідно до вимог ДСТУ БВ.2.7. -71 Будівельні матеріали.

Таблиця 8

Фізико-механічні властивості карбонатних порід

\begin{tabular}{|c|c|c|c|c|}
\hline $\begin{array}{c}\text { Номер } \\
\text { проби }\end{array}$ & $\begin{array}{c}\text { Вирбо } \\
\text { породи }\end{array}$ & $\begin{array}{c}\text { Водопогли- } \\
\text { нання, \% }\end{array}$ & $\begin{array}{c}\text { Уежа муцності на стискання } \\
\text { стані }\end{array}$ & $\begin{array}{c}\text { у водонасиченому } \\
\text { стані }\end{array}$ \\
\hline 1 & Б & размокає & $\begin{array}{c}\text { не } \\
\text { визначалася }\end{array}$ & 0,2 \\
\hline 2 & Л & 27,90 & 4,5 & 0,7 \\
\hline
\end{tabular}

Таблиця 9

Хімічний склад крейдяної породи

\begin{tabular}{|c|c|c|c|c|c|c|c|c|c|}
\hline \multirow{2}{*}{ Вид } & \multicolumn{7}{|c|}{ Вміст основних оксидів,\% } & \multirow{2}{*}{ ППП } \\
\cline { 2 - 10 } & $\mathrm{CaO}$ & $\mathrm{MgO}$ & $\mathrm{Si}_{2}$ & $\mathrm{AI}_{2} \mathrm{O}_{3}$ & $\mathrm{Fe}_{2} \mathrm{O}_{3}$ & $\mathrm{Na}_{2} 0$ & $\mathrm{~K}_{2} 0$ & $\mathrm{~S}_{3}$ & \\
\hline Б & 55,10 & $<0,1$ & 0,94 & 0,10 & 0,10 & 0,16 & 0,10 & $<0,02$ & 43,56 \\
\hline Л & 51,69 & $<0,1$ & 7,50 & 1,07 & 0,34 & 0,28 & 0,24 & $<0,02$ & 38,77 \\
\hline
\end{tabular}

Таблиця 10

Мінералогічний склад крейдяної породи

\begin{tabular}{|c|c|c|c|c|c|}
\hline \multirow{2}{*}{$\begin{array}{c}\text { Вид } \\
\text { породи }\end{array}$} & \multicolumn{5}{|c|}{ Вміст основних оксидів,\% } \\
\cline { 2 - 6 } & $\mathrm{CaCO}_{3}$ & $\mathrm{MgO}$ & $\mathrm{SiO}_{2}$ & $\mathrm{Al}_{2} \mathrm{O}_{3}$ & $\mathrm{Fe}_{2} \mathrm{O}_{3}$ \\
\hline Б & 98,39 & $<0,1$ & 0,94 & 0,10 & 0,10 \\
\hline Л & 92,30 & $<0,1$ & 7,50 & 1,07 & 0,34 \\
\hline
\end{tabular}

${ }^{17}$ Терриконы : монография / Л.Г. Зубова, А.Р. Зубов, А.А. Зубов и др. Луганск : Изд-во Ноулидж, $2015.716 \mathrm{c}$.

${ }^{18}$ Там само. 
Хімічний склад крейди (рис. 7) визначався згідно з ГОСТ 21138.5-78.

Фракційний склад породи: крейдяна порода Л: $25 \%$ - фракція розміром 0-2 см; 50\% - 2-5 см; $25 \%$ - більше 5 см; порода Б: $70 \%-$ $0-2 \mathrm{~cm} ; 30 \%-2-5 \mathrm{~cm}$.

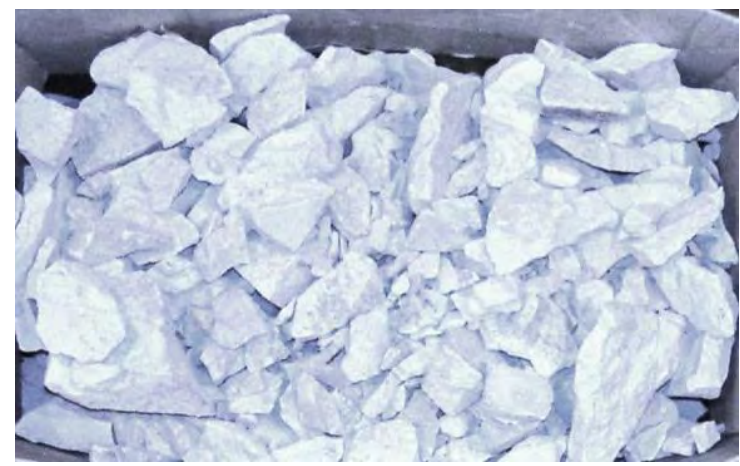

A

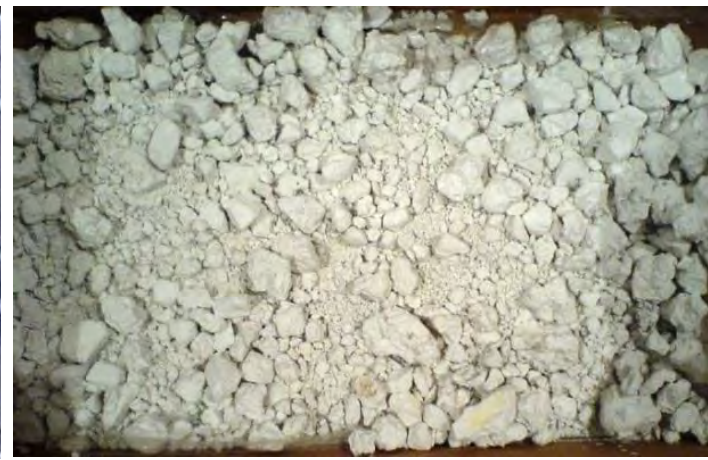

Б

Рис. 7. Види карбонатної породи, використаної у дослідах: а - $з$ кар'єру в м. Луганськ (Л); б - із Білогорівського кар'єру (Б)

Дистильовану воду розбавили фіксоналом до рН 2,65 і пропускали через фільтраційну установку діаметром 8,6 см заввишки $30 \mathrm{~cm}$ (для фракцій 0-2, 2-5 см), на дно якої поклали шар гравію заввишки 4 см, вище - шар крейдяної породи висотою 8 см. Для фракцій $>5$ і суміші фракцій 0-2, 2-5, >5 використовували установку діаметром 16 см (рис. 8). Досвід повторили 10 разів, використовуючи розчин із вихідною кислотністю, імітуючи проходження через породу великої кількості кислої води.

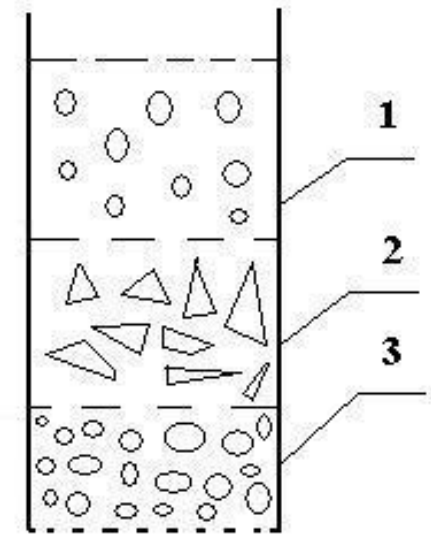

Рис. 8. Схема фільтраційної установки: 1 - шар води, 2 - шар карбонатної породи, 3 - шар гравію 
Після кожного пропускання відбирали пробу води, яка профільтрувалася, і визначали iї pH. Відзначали час фільтрації, сухий залишок і кількість сульфат-іонів на виході. На підставі результатів дослідів (табл. 11) можна зробити висновок, що здатність карбонатної породи до нейтралізації кислих стоків різна. Для більшої наочності відмінних ознак побудовано графік залежності зміни $\mathrm{pH}$ від кількості пропускання кислих стоків через породу (рис. 9).

Таблиця 11

Результати нейтралізації кислих стоків із використанням різних фракцій і видів карбонатної породи

\begin{tabular}{|c|c|c|c|c|c|c|c|c|c|c|c|c|c|}
\hline \multirow{2}{*}{ № } & \multirow{2}{*}{$\begin{array}{l}\frac{\pi}{0} \\
0 \\
0 \\
0 \\
0\end{array}$} & \multirow{2}{*}{$\begin{array}{c}\text { Фракційний } \\
\text { склад, см }\end{array}$} & \multirow{2}{*}{$\begin{array}{c}\text { pH } \\
\text { на } \\
\text { вході }\end{array}$} & \multicolumn{10}{|c|}{$\begin{array}{l}\text { Водневий показник рН води на виході } \\
\text { із фільтраційної установки }\end{array}$} \\
\hline & & & & 1 & 2 & 3 & 4 & 5 & 6 & 7 & 8 & 9 & 10 \\
\hline 1 & \multirow{5}{*}{ Л } & $<2$ & 2,65 & 7,45 & 7,35 & 7,30 & 7,12 & 6,88 & 6,75 & 6,20 & 5,81 & 4,72 & 3,69 \\
\hline 2 & & $2-5$ & 2,65 & 7,35 & 7,30 & 7,25 & 7,10 & 6,85 & 6,70 & 6,15 & 5,70 & 4,65 & 3,58 \\
\hline 3 & & $>5$ & 2,65 & 7,25 & 7,16 & 6,15 & 5,20 & 4,30 & 3,21 & 3,12 & 3,06 & 3,04 & 3,05 \\
\hline 4 & & $<2,2-5,>5$ & 2,65 & 7,30 & 7,20 & 6,35 & 5,80 & 4,90 & 4,05 & 3,60 & 3,15 & 3,08 & 3,08 \\
\hline 5 & & $<2,2-5,>5$ & 3,65 & 7,35 & 7,27 & 6,48 & 6,20 & 5,35 & 4,77 & 4,25 & 4,14 & 4,11 & 4,12 \\
\hline 6 & \multirow{2}{*}{5} & $<2$ & 2,65 & 7,60 & 7,55 & 7,45 & 7,35 & 7,30 & 7,20 & 7,10 & 7 & 6,90 & 6,82 \\
\hline 7 & & $2-5$ & 2,65 & 7,55 & 7,48 & 7,36 & 7,25 & 7,16 & 7,04 & 7,02 & 6,80 & 6,67 & 6,50 \\
\hline
\end{tabular}
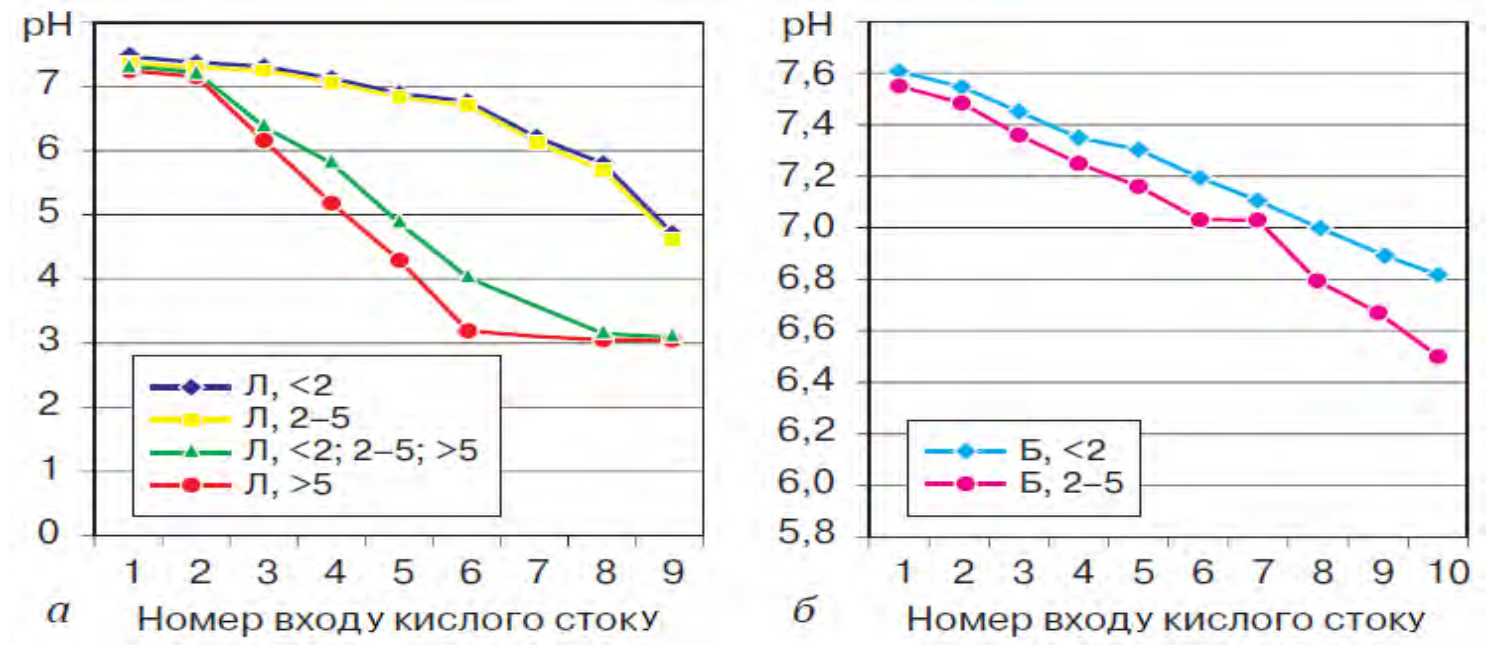

Рис. 9. Графіки зміни кислотності на виході із фільтраційної установки: а - порода Л, фракції 0-2, 2-5, >5 і їх суміш; б - порода Б, фракції 0-2, 2-5 см

Аналіз рис. 9 дозволяє констатувати таке:

- рівень нейтралізації кислих вод при початковому етапі (1-3 пропускання) тримається на досить високому рівні незалежно від виду карбонатної породи та розмірів фракції; 
- починаючи з 4-го входу рівень рН істотно різниться: для фракцій породи Л розміром 0-2 і 2-5 см відбувається поступове зниження водневого показника до рівня 3,69 ; для фракцій породи $>5$ см і суміші 0-2, 2-5, >5 см відбувається різке зниження рН до 3,15; при $\mathrm{pH} 3,08$ відбувається його стабілізація;

- рівень нейтралізації кислих стоків із використанням фракцій карбонатної породи Б розміром 0-2 і 2-5 см зберігається досить високим при всіх десяти циклах промивання, поступово знижуючись із $\mathrm{pH} 7,6$ до 6,50.

Для 3'ясування інтенсивності виносу частинок крейди з установки була визначена маса осаду у пробах фільтрату (табл. 12).

Таблиця 12

Маса сухого залишку на виході із фільтраційної установки

\begin{tabular}{|c|c|c|c|c|c|c|c|c|c|c|c|}
\hline \multirow{2}{*}{$№$} & Порода, & \multicolumn{10}{|c|}{ Паса сухого залишку, г } \\
\cline { 3 - 12 } фракції, см & 1 & 2 & 3 & 4 & 5 & 6 & 7 & 8 & 9 & 10 \\
\hline 1 & Л, 0-2 & 1,76 & 0,63 & 0,50 & 0,32 & 0,24 & 0,15 & 0,14 & 0,06 & 0,04 & 0,04 \\
\hline 2 & Л, 2-5 & 0,87 & 0,53 & 0,26 & 0,13 & 0,13 & 0,12 & 0,07 & 0,03 & 0,06 & 0,25 \\
\hline 3 & Л, 5< & 5,68 & 1,48 & 0,51 & 0,27 & 0,20 & 0,17 & 0,14 & 0,12 & 0,08 & 0,07 \\
\hline 4 & Л, 0-2, 2-5, $>5$ & 7,43 & 1,86 & 0,68 & 0,40 & 0,29 & 0,20 & 0,15 & 0,13 & 0,11 & 0,10 \\
\hline 5 & Б, 0-2 & 52,3 & 51,6 & 16,3 & 8,75 & 4,84 & 3,87 & 2,85 & 2,76 & 2,12 & 1,65 \\
\hline 6 & Б, 2-5 & 32,4 & 22,0 & 4,35 & 3,98 & 2,72 & 2,25 & 1,24 & 0,94 & 0,87 & 0,61 \\
\hline
\end{tabular}

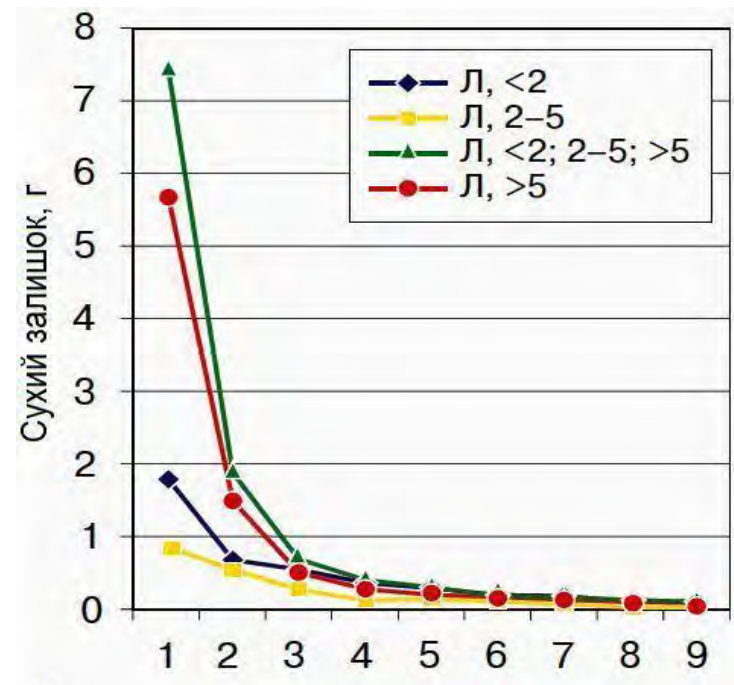

$a \quad$ № фıльтрацийного виходу

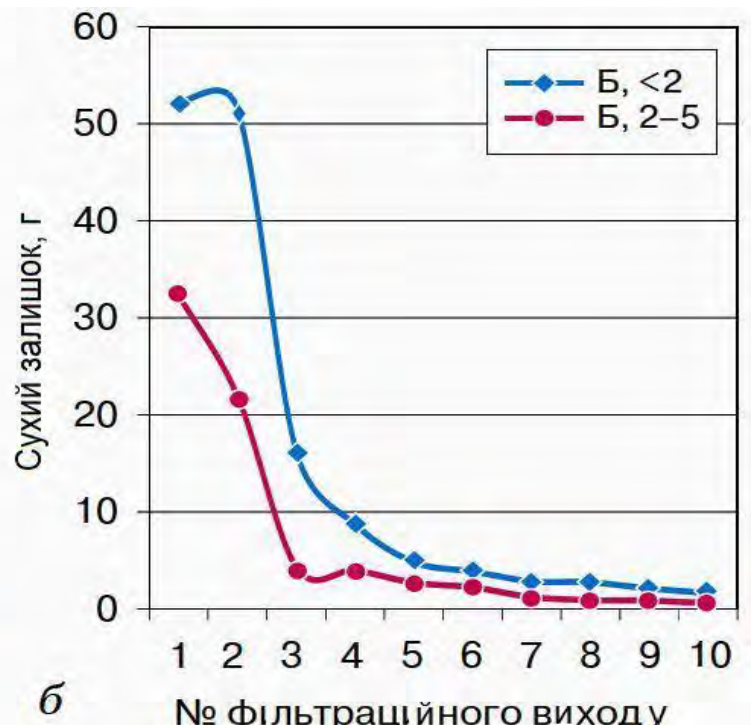

б

Рис. 10. Графіки зміни кількості осаду залежно від циклу фільтрації: а - для різних фракцій і їх суміші породи «Л»; б - для різних фракцій породи «Б»

На підставі рис. 10 можна зробити висновок, що швидкість винесення частинок крейди зі зразків породи після другого циклу різко знизилася. 
Таким чином, фізичне моделювання лужних геохімічних бар'єрів $Д_{1}$, які формуються при окисленні сульфідних руд, котрі залягають у вапняках, показало, що різні карбонатні породи мають різну здатність до нейтралізації кислих стоків та утворення твердої фази. Деякі вапняки можуть виступати як геохімічний бар'єр Д 1 для сірчанокислих стоків до певної межі, а далі тверді осади при взаємодії сульфату торію 3 вапняками можуть не формуватися, $\mathrm{pH}$ - майже не змінюватися. Розчин після взаємодії з такими вапняками залишається кислим.

Сульфат торію, який утворився і не «піддався» повній нейтралізації у вапняках, зберігає низьке значення $\mathrm{pH}$, продовжує вимивати торій із мінералів (підвищуючи свою концентрацію), а при випадінні атмосферних опадів переходить у водний розчин і знаходиться в ньому без змін у діапазоні температур від 0 до $20^{\circ} \mathrm{C}$.

Внаслідок випадіння атмосферних опадів, розведення водних розчинів, зростання $\mathrm{pH}$ вище 3,5 за температури понад $20^{\circ} \mathrm{C}$ відбувається осадження торію (при переході водного розчину зі стану гелю в золь) у вигляді його гідроксиду. Оскільки колоїди торію належать до гідрофобних, що створюють при коагуляції гелі, майже не містять води, або порошки - седимент, гідроксид торію $\mathrm{Th}(\mathrm{OH})_{4}$, який утворився у водному розчині при переході в золь, може майже не містити воду або перебувати у вигляді седиментів. Процеси окислення сульфідних руд $\epsilon$ високотемпературними та пов'язані з утворенням сірки, займистої за температури $248 \ldots 261^{\circ} \mathrm{C}$, тож виникає процес стійкого горіння продуктів термічної деструкції та газифікації гірської породи 3 температурою до $1000^{\circ} \mathrm{C}$ i вище. Внаслідок горіння утворюються розплави солей. Метали в розплавлених при $500-1200^{\circ} \mathrm{C}$ солях розчиняються, і седимент гідроксиду торію $\mathrm{Th}(\mathrm{OH})_{4}$ може легко розчинятися в розплавах солей. Також відомим $є$ факт розкладання $\mathrm{Th}(\mathrm{OH})_{4}$ за температури $>470^{\circ} \mathrm{C}$ на $\mathrm{ThO}_{2}$ i $\mathrm{H}_{2} \mathrm{O}$.

Що ж відбувається із розчиненим в атмосферних опадах сульфатом торію за температури, нижчої за $0^{\circ} \mathrm{C}$ ? Для відповіді на це питання були проведені досліди із заморожуванням води згідно 3 матрицею планування експерименту (табл. 13), виконано аналіз поведінки солей, що містяться в розчині ${ }^{19}$.

Зразки води заморожувалися в літрових ємностях у зимовий період на відкритому повітрі. Смності витримувалися на морозі різний час із метою отримання різного сполучення замерзлої та незамерзлої води. Через деякий час, коли співвідношення льоду і води склало приблизно 1 до 4, через фільтр злили воду в мірний посуд - варіант $\mathrm{a}_{1} \mathrm{~b}_{1}($ н). Лід, що залишився в ємності, внесли у приміщення для танення - варіант $\mathrm{a}_{1} \mathrm{~b}_{1}(\mathrm{~T})$. Аналогічно вчинили і з іншими ємностями: зі співвідношенням

\footnotetext{
19 Зубова Л.Г., Зубов О.Р. Гідроекологічні проблеми Донбасу. Луганськ : Вид-во ЛНУ ім. В. Даля, 2008. $100 \mathrm{c}$. 
льоду до незамерзлої води 2:3 (варіанти $\mathrm{a}_{1} \mathrm{~b}_{2}(\mathrm{~T})$ i $\mathrm{a}_{1} \mathrm{~b}_{2}(\mathrm{H})$ ) i 3:1 (варіанти $\mathrm{a}_{1} \mathrm{~b}_{3}(\mathrm{~T})$ i $\left.\mathrm{a}_{1} \mathrm{~b}_{3}(\mathrm{H})\right)$.

Таблиця 13

Матриця планування експерименту

\begin{tabular}{|c|c|c|}
\hline № варианта & Сполучення факторів & Код варианту \\
\hline 1 & $\mathrm{a}_{0} \mathrm{~b}_{0}$ & $\mathrm{a}_{0} \mathrm{~b}_{0}$ \\
\hline 2 & \multirow{2}{*}{$\mathrm{a}_{1} \mathrm{~b}_{1}$} & $\mathrm{a}_{1} \mathrm{~b}_{1}(\mathrm{H})$ \\
\cline { 1 - 2 } 3 & \multirow{2}{*}{$\mathrm{a}_{1} \mathrm{~b}_{1}(\mathrm{~T})$} \\
\hline 4 & $\mathrm{a}_{2}$ & $\mathrm{a}_{1} \mathrm{~b}_{2}(\mathrm{H})$ \\
\hline 5 & $\mathrm{a}_{1} \mathrm{~b}_{3}$ & $\mathrm{a}_{1} \mathrm{~b}_{2}(\mathrm{~T})$ \\
\hline 6 & & $\mathrm{a}_{1} \mathrm{~b}_{3}(\mathrm{H})$ \\
\hline 7 & $\mathrm{a}_{1} \mathrm{~b}_{3}(\mathrm{~T})$ \\
\hline
\end{tabular}

$\mathrm{a}_{0}$ - контроль (вода без заморожування); $\mathrm{a}_{1}$ - заморожування; $\mathrm{b}$ - ступінь заморожування: $\mathrm{b}_{0}-0 \%$, вода без заморожування (контроль досліду); $\mathrm{b}_{1}$ - заморожена до отримання близько $20 \%$ льоду; $\mathrm{b}_{2}$ - близько $50 \%$ замороженої води; $\mathrm{b}_{3}$ - близько $80 \%$ замороженої води; н - незамерзла вода; т - тала вода (розтоплений лід).

Для визначення концентрації головних іонів - кальцію і магнію методом титрування було використано хлороген чорний, аміачний буферний розчин, трилон Б. Результати досліду представлено у табл. 14, на підставі якої побудовано графіки залежності концентрації іонів кальцію і магнію від ступеня замерзання. На рис. 11 явно простежується закономірність підвищення концентрації $\left(\mathrm{Ca}^{2+}\right)+\left(\mathrm{Mg}^{2+}\right)$ у незамерзлій воді за ступенем замерзання води у пробі. Іншими словами, чим менше води, що не замерзла, тим більша в ній концентрація $\left(\mathrm{Ca}^{2+}\right)+\left(\mathrm{Mg}^{2+}\right)$. У талій воді, навпаки, при замерзанні води концентрація іонів $\left(\mathrm{Ca}^{2+}\right)+$ $\left(\mathrm{Mg}^{2+}\right)$ у льоді, який утворюється, різко зменшується у два рази, незалежно від співвідношення льоду і води, що не замерзла.

Таблиця 14

Розрахунок концентрації $\left(\mathrm{Ca}^{2+}\right)+\left(\mathrm{Mg}^{2+}\right)$

\begin{tabular}{|c|c|c|c|c|c|}
\hline \multirow[b]{2}{*}{$\begin{array}{c}\text { Сполучення } \\
\text { факторів }\end{array}$} & \multirow[b]{2}{*}{$\begin{array}{c}\text { Код } \\
\text { проби }\end{array}$} & \multirow{2}{*}{$\begin{array}{c}\text { Співвідно- } \\
\text { шення н/т, } \\
\%\end{array}$} & \multicolumn{3}{|c|}{ Титрування } \\
\hline & & & $\begin{array}{c}\mathrm{V}_{\text {трилон б, }}, \\
\text { МЛ }\end{array}$ & $\mathrm{V}_{\text {вода, }}$ Мл & $\begin{array}{c}\left(\mathrm{Ca}^{2+}\right)+\left(\mathrm{Mg}^{2+}\right) \\
\text { мГ/л }\end{array}$ \\
\hline$a_{0} b_{0}$ & $a_{0} b_{0}(H)$ & 100 & 9,6 & \multirow{7}{*}{25} & 384 \\
\hline \multirow{2}{*}{$a_{1} b_{1}$} & $a_{1} b_{1}(H)$ & 80 & 10,1 & & 404 \\
\hline & $a_{1} b_{1}(\mathrm{~T})$ & 20 & 4,8 & & 192 \\
\hline \multirow{2}{*}{$a_{1} b_{2}$} & $a_{1} b_{2}(H)$ & 40 & 16,3 & & 652 \\
\hline & $\mathrm{a}_{1} \mathrm{~b}_{2}(\mathrm{~T})$ & 60 & 4,8 & & 192 \\
\hline \multirow{2}{*}{$a_{1} b_{3}$} & $a_{1} b_{3}(H)$ & 24 & 18,7 & & 748 \\
\hline & $a_{1} b_{3}(T)$ & 76 & 4,6 & & 184 \\
\hline
\end{tabular}




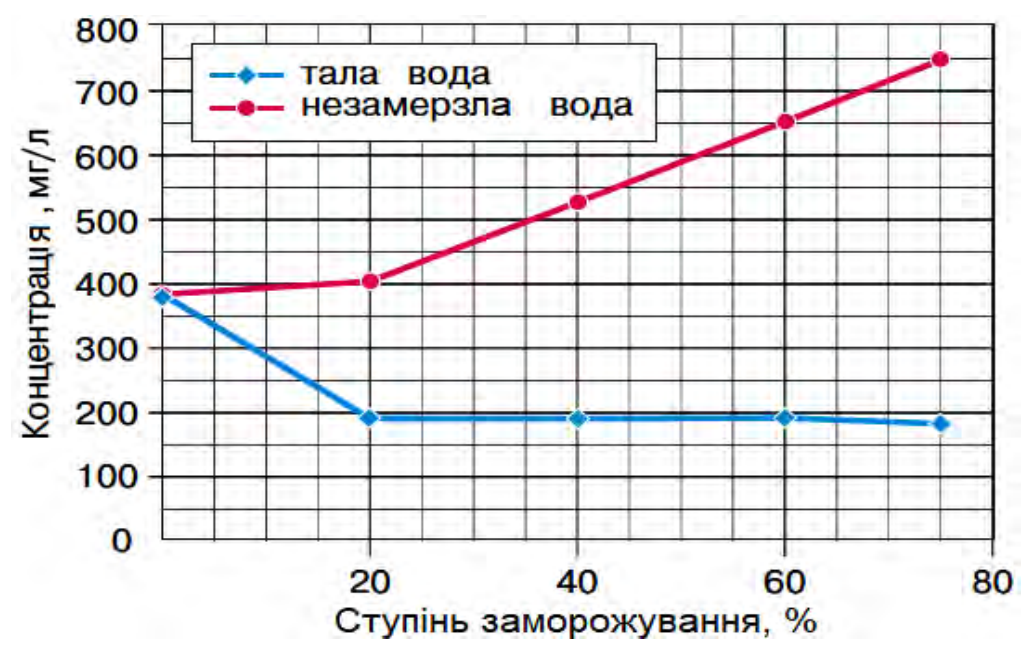

\section{Рис. 11. Концентрація кальцію і магнію у незамерзлій і талій воді}

Таким чином, фізичне моделювання процесу заморожування води у природі й аналіз поведінки солей, що містяться в розчині, дозволили виявити таке: 3 області замерзання солі переходять у незамерзаючу частину, одночасно відбувається часткове випадання солей в осад; лід, який утворюється, характеризується зниженим вмістом солей відносно їх вихідного вмісту у воді до замерзання; проте в незамерзлій воді відбувається зростання їх концентрації, тобто формується відносно чистий лід і дедалі більш концентрований розсіл. А якщо в ході заморожування замерзає вся вода, 3 неї, як можна побачити після розморожування, надлишок солей випадає в осад.

Виходячи з вищевикладеного, можна сформулювати деякі положення.

1. На ділянках, де $\epsilon$ сульфіди, відбувається їх окислення з утворенням сірчаної кислоти. Внаслідок ії взаємодії з торій-вміщуючими мінералами утворюються сульфати торію.

2. Сірчанокислі розчини, що несуть метали (у т. ч. й торій), взаємодіють із вміщуючими вапняками й усереднюються. Внаслідок підвищення $\mathrm{pH}$ на лужному бар'єрі осідає частина речовин у вигляді гіпсу і карбонату торію.

3. Та частина сульфату торію, яка не «піддалася» процесу його нейтралізації у вапняках, зберігає низький $\mathrm{pH}$, вимиває торій із мінералів (підвищуючи його концентрацію), розчиняється у воді атмосферних опадів у діапазоні температур від $0^{\circ} \mathrm{C}$ до $20^{\circ} \mathrm{C}$.

4. За температури, вищої за $20^{\circ} \mathrm{C}$, відбувається осадження торію у вигляді його гідроксиду (при переході водного розчину зі стану гелю в золь). Оскільки колоїди торію належать до гідрофобних, що утворюють при коагуляції гелі, які майже не містять воду, або порошки - седимент, гідроксид торію $\mathrm{Th}(\mathrm{OH})_{4}$, що утворився у водному розчині при переході в золь, може майже не містити воду або перебувати у вигляді седимента. 
5. Оскільки процеси окислення сульфідних руд $\epsilon$ високотемпературними та пов'язані з утворенням сірки, займистої при $248 \ldots 261^{\circ} \mathrm{C}$, виникає процес стійкого горіння продуктів термічної деструкції та газифікації гірської породи з температурою до $1000^{\circ} \mathrm{C} \mathrm{i}$ вище. Внаслідок горіння утворюються розплави солей. Оскільки метали в розплавлених за температури $500-1200^{\circ} \mathrm{C}$ солях розчиняються, седимент гідроксиду торію $\mathrm{Th}(\mathrm{OH})_{4}$ легко розчиняється у розплавах солей (рис. 12).

6. За температури менше $0^{\circ} \mathrm{C}$ частина солей торію поступово йде 3 льоду в концентрований розсіл, а після його замерзання і подальшого відтавання - випадає в осад.

7. Концентрований осад солей торію, що формується внаслідок заморожування водних розчинів, так само, як і седимент гідроксиду торію $\mathrm{Th}(\mathrm{OH})_{4}$ легко розчиняється в розплавах солей, які утворюються внаслідок високотемпературного окислення сульфідів.

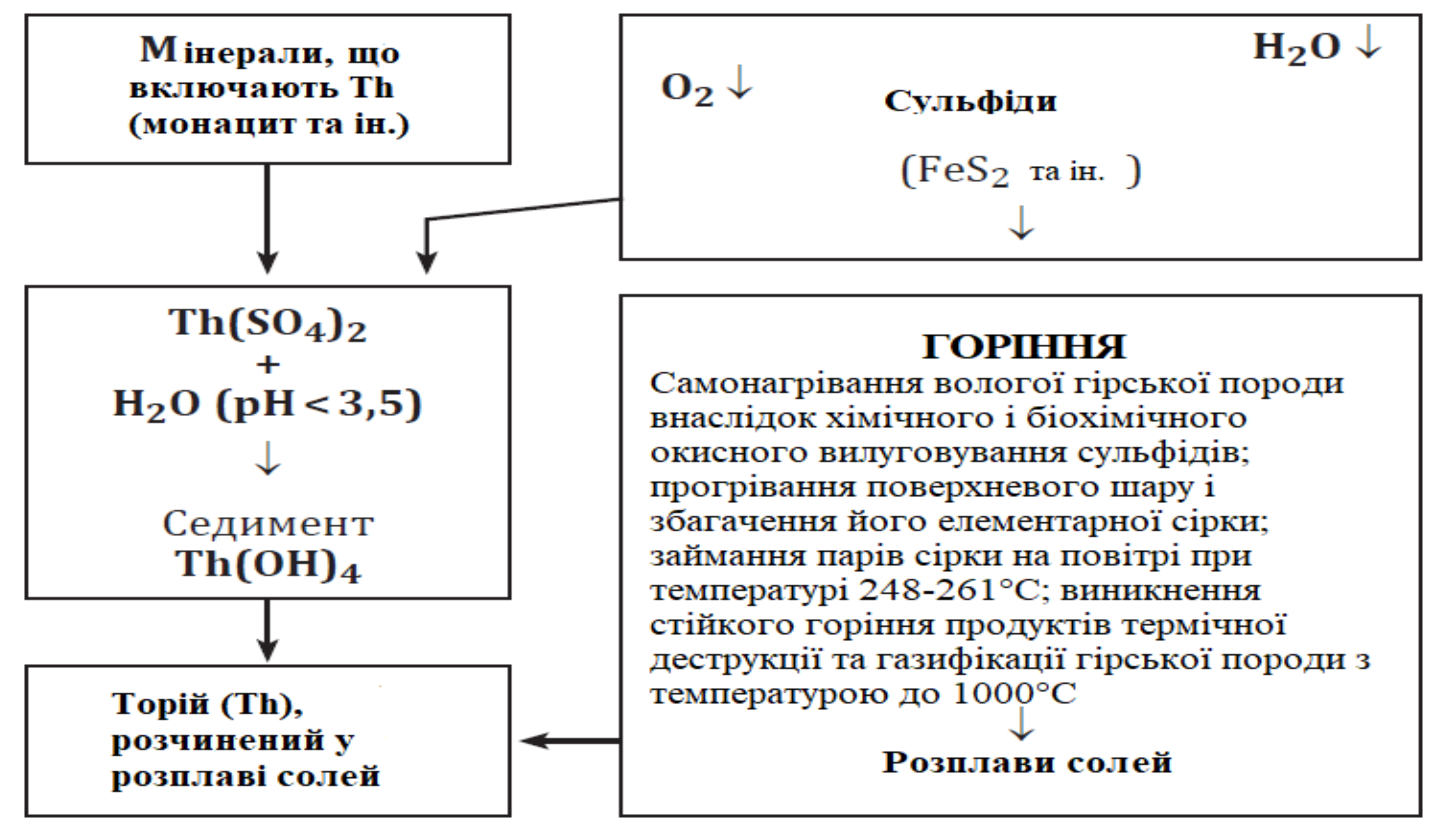

Рис. 12. Процес «розчинення» торію концентрованою сірчаною кислотою, що утворюється в зоні окислення сульфідів на лужному $Д_{1}$, кислому Е геохімічних бар'єрах $^{20,21}$

При впливі нейтронів ззовні радіоактивний торій, сконцентрований внаслідок осадження торію у вигляді гідроксиду або після його замерзання (листопад-березень) у вигляді солей, здатний до ядерного

\footnotetext{
20 Зубова Л.Г. Торий в природе и в сернокислых ландшафтах (научные факты и гипотезы) : монография. Луганск : Изд-во «Ноулидж», 2017.72 с.

21 Зубова Л.Г. Глобальные катастрофические явления в угледобывающей промышленности разных стран. Уголь Украиныл. 2018. № 3. С. 39-47.
} 
поділу. Джерелом нейтронів для реакції поділу може виступити гроза плазма (газ, іонізований у певному обсязі) передає нейтрони за допомогою електричних сил.

Згідно зі спогадами очевидців звуки, які супроводжували Тунгуський метеорит (явище, що спостерігалося у 1908 р. в Тунгуському вугільному басейні), нагадували безперервні грозові удари ${ }^{22}$.

При взаємодії «розкритого» торію 3 нейтронами грози та ядерному розщепленні все «металеві» дочірні елементи переходять із кристалічної решітки у розплави солей. Тільки ${ }^{220} \mathrm{Rn}$ (торон) із тривалістю життя $55 \mathrm{c}$ у вигляді газоподібного згустку (кульової блискавки) залишає межі обсягу іонізації (плазми). Наслідками ділення торію, що має характер вибуху, є або (в районах вічної мерзлоти - кріозоні) «падаючі псевдометеоріти» (рис. 13, інтернет), оскільки вибух не здатний пробити товщу вічної мерзлоти, або (на ділянках відсутності вічної мерзлоти) карстові прояви.

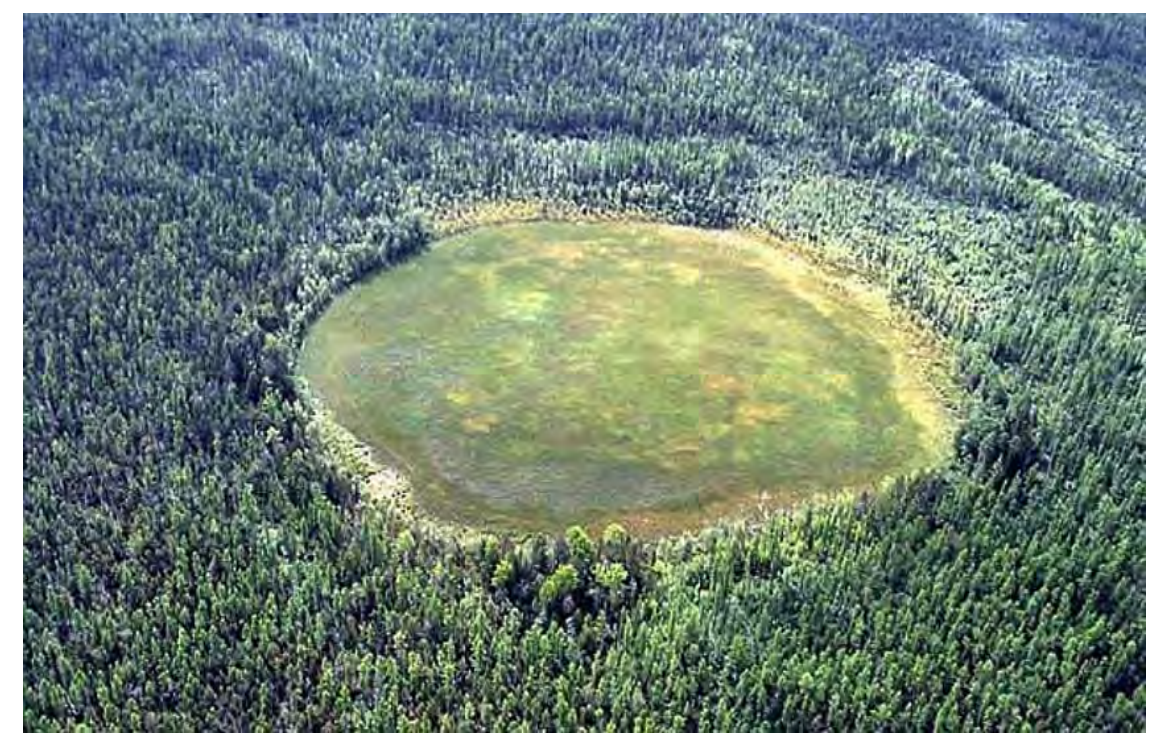

Рис. 13. «Псевдометеоритний» кратер

у Тунгуському вугільному басейні

Французький дослідник карсту Е. Мартель пропонував називати карстові явища «явищами у вапняках». Монографія про карст сербського географа Й. Цвійіча також названа «Географія вапнякових земель» ${ }^{23}$.

Якщо звернутися до аналізу географічного розташування карсту, то слід зазначити, що на Донецькому кряжі карст знаходиться переважно в нижньокам'яновугільних вапняках, в Іркутському вугільному басейні -

\footnotetext{
22 Зубова Л.Г. Торий в природе и в сернокислых ландшафтах (научные факты и гипотезы) : монография. Луганск : Изд-во «Ноулидж», 2017. 72 с.

${ }^{23}$ Гвоздецкий Н.А. Карст. Москва : Мысль, 1981. 214 с.
} 
у вугленосних шарах у нижньокембрійських доломітах і вапняках; поширений він у кам'яновугільних родовищах на південь від Москви; карбонатний карст розвинутий у Тунгуському вугільному басейні та ін. ${ }^{24}$

Н.А. Гвоздецький у своїй книзі «Карст» ${ }^{25}$ пише, що в Канаді спостерігається карст, який поєднується 3 вічною мерзлотою. Нами висунуто припущення, що на ділянках розташування розроблюваних вугільних родовищ, де немає вічної мерзлоти, ядерний поділ торію має викликати карстування вапняків, а на територіях із товщею непробивної вічної мерзлоти - вибух болідів. У табл. 15 представлено відомості про наявність падіння болідів і карсту у вапняках вугледобувних провінцій і територій Канади: Британської Колумбії, Альберти, Саскачеван, Нової Шотландії та ін.

Таблиця 15

Наслідки ядерного ділення торію у вигляді падіння болідів або наявності карсту на територіях поблизу розроблюваних вугільних родовищ Канади

\begin{tabular}{|c|c|c|}
\hline $\begin{array}{l}\text { Вугледобувні } \\
\text { провінції і } \\
\text { території }\end{array}$ & $\begin{array}{c}\text { Назва і дата падіння } \\
\text { метеоритів }\end{array}$ & Наявність карсту \\
\hline $\begin{array}{l}\text { Британська } \\
\text { Колумбія }\end{array}$ & $\begin{array}{l}18.01 .2000 \\
5.09 .2017\end{array}$ & $\begin{array}{l}\text { 1). У південній частині передового } \\
\text { хребта Скелястих гір, вздовж кордону } \\
\text { провінції Британська Колумбія. } \\
\text { 2). У центральній області Кордильєр } \\
\text { Британської Колумбії, у Фелкленді. } \\
\text { 3). Південний захід Британської } \\
\text { Колумбії, зона Берегового хребта й } \\
\text { о. Ванкувер. }\end{array}$ \\
\hline Альберта & $\begin{array}{l}\text { 1952, Abbe } \\
\text { 1960, Bruderheim } \\
\text { 1963, Peace River } \\
\text { 2008, Buzzard Coulee } \\
\text { 22.11.2008 } \\
5.09 .2017 \\
24.11 .2017\end{array}$ & $\begin{array}{l}\text { 1). У південній частині передового } \\
\text { хребта Скелястих гір, вздовж кордону } \\
\text { провінції Альберта. } \\
\text { 2). На території із відкладеннями гіпсу } \\
\text { і солі (в породах середнього девону) } \\
\text { східної частини Великих рівнин (на } \\
\text { північному сході провінції Альберта) } \\
\text { є нетектонічні деформації та воронки. }\end{array}$ \\
\hline Саскачеван & $\begin{array}{l}\text { 1931, Springwater } \\
22.11 .2008 \\
22.02 .2012 \\
24.11 .2017\end{array}$ & $\begin{array}{l}\text { На півдні провінції Саскачеван } \\
\text { спостерігаються численні явища } \\
\text { підземного вилуговування солей. }\end{array}$ \\
\hline $\begin{array}{l}\text { Нова Шотландія, } \\
\text { Нью Брансвік та ін. }\end{array}$ & 18.03 .2014 & $\begin{array}{l}\text { На півострові Нова Шотландія } \\
\text { розвинений гіпсовий карст. }\end{array}$ \\
\hline
\end{tabular}

${ }_{25}^{24}$ Там само

25 Там само. 


\section{3. Діяльність торію в сірчанокислих ландшафтах природного} (вулканах) і антропогенного (відвалах вугільних шахт) походження

Для дослідження присутності торію у вулканах використовували природні геологічні утворення, знайдені нами на території Коктебельської долини поблизу вулкану Кара-Даг (рис. 14) ${ }^{26}$.
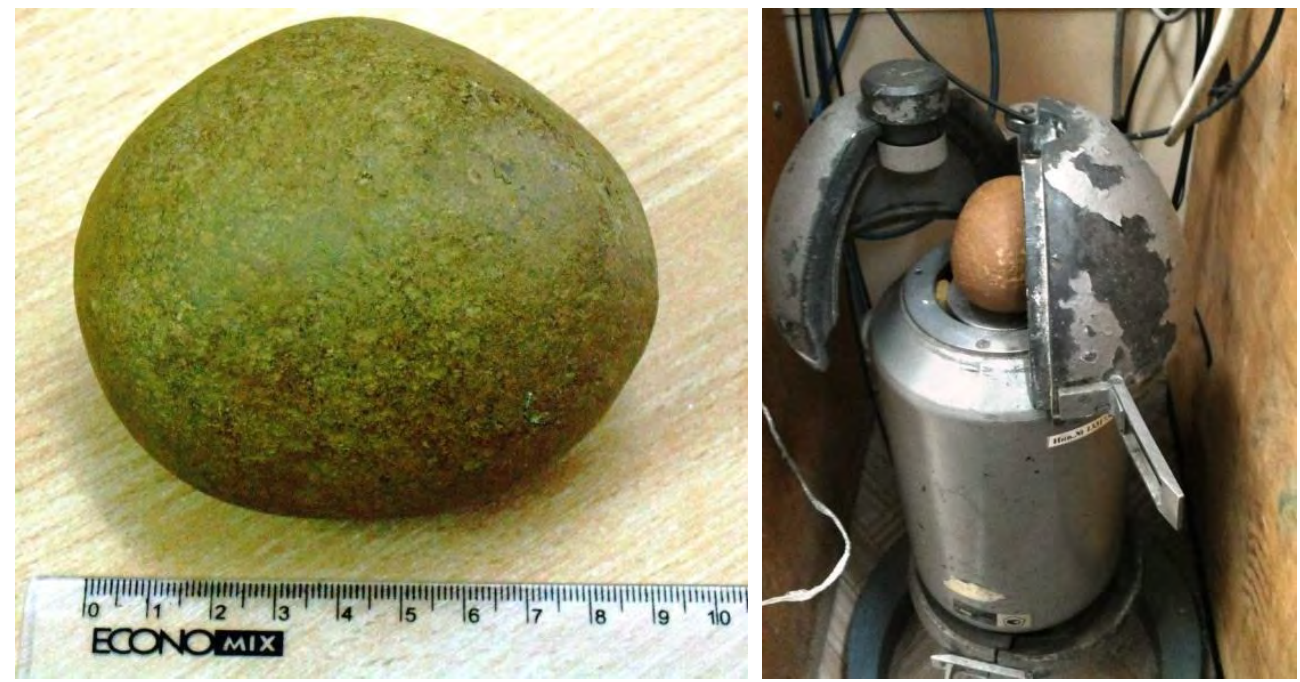

Рис. 14. Дослідження вулканічних утворень на установці РИТМ-С ${ }^{10}$

Вулканічні утворення досліджували на спектрометричній установці «РИТМ-С» (див. рис. 14). Наочний вид отриманих спектрів ПРН представлено на рис. 15 , а протокол обробки - у табл. $16^{27}$.
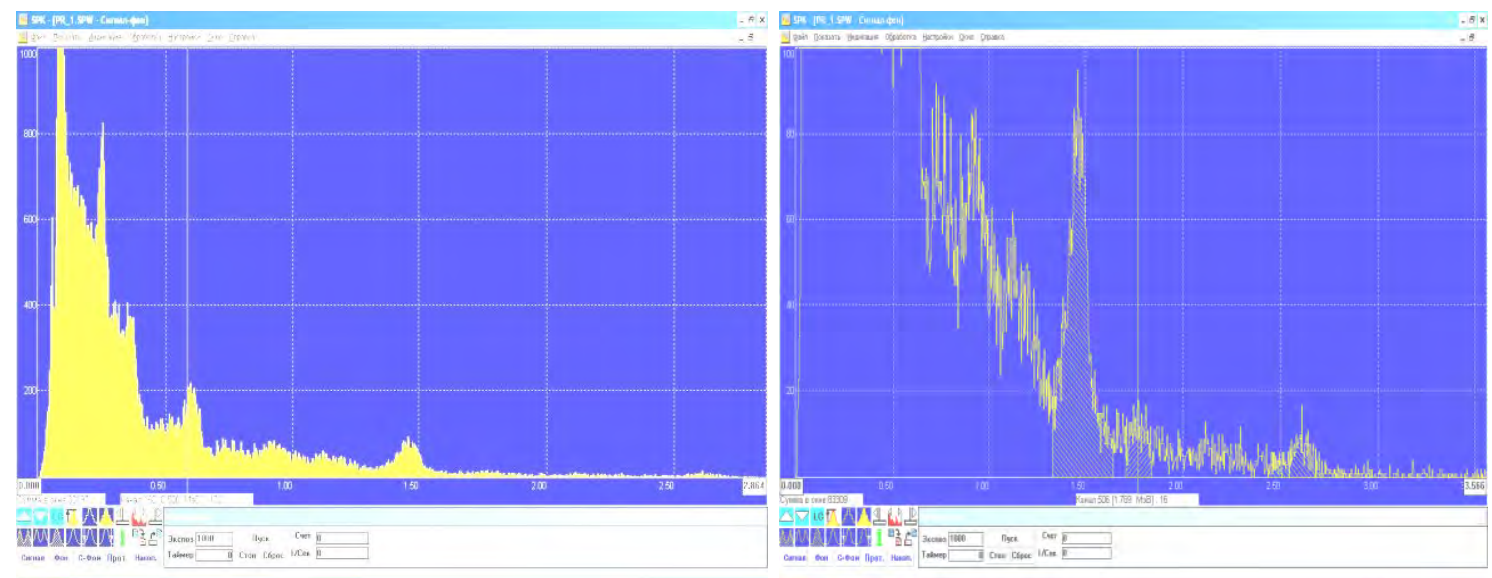

Рис. 15. Обробка енергетичних спектрів вулканічних утворень

\footnotetext{
26 Зубова Л.Г. Торий в природе и в сернокислых ландшафтах (научные факты и гипотезы) : монография. Луганск : Изд-во «Ноулидж», 2017. 72 с.

${ }^{27}$ Там само. 
Таблиця 16

\section{Протокол обробки спектра гамма-випромінювання} вулканічних утворень

\begin{tabular}{|c|c|c|c|c|c|c|}
\hline \multirow{2}{*}{$\begin{array}{c}\text { № } \\
\Pi / \Pi\end{array}$} & \multirow{2}{*}{ Нуклід } & \multicolumn{2}{|c|}{ Активність } & \multicolumn{2}{|c|}{ Питома активність } & \multirow{2}{*}{$\begin{array}{c}\text { Похибка активності, } \\
\%\end{array}$} \\
\hline & & Бк & мкКи & Бк/кг & мкКи/кг & \\
\hline 1 & ${ }^{232} \mathrm{Th}$ & 69,3 & 0,0019 & 68,8 & 0,0019 & 10,2 \\
\hline 2 & ${ }^{226} \mathrm{Ra}$ & - & - & - & - & - \\
\hline 3 & ${ }^{40} \mathrm{~K}$ & 901 & 0,0244 & 894,7 & 0,0242 & 17,2 \\
\hline 4 & ${ }^{137} \mathrm{Cs}$ & - & - & - & - & - \\
\hline \multicolumn{2}{|c|}{$\begin{array}{l}\text { Емність судини } \\
\text { Марінелі, см }{ }^{3}\end{array}$} & \multicolumn{2}{|c|}{ Маса проби } & \multicolumn{2}{|c|}{$\begin{array}{l}\text { Питома ефективна } \\
\text { активність, Бк/кг }\end{array}$} & $\begin{array}{c}\text { Час виміру } \\
\text { (експозиція), с }\end{array}$ \\
\hline \multicolumn{2}{|c|}{1000} & \multicolumn{2}{|c|}{1,0070} & \multicolumn{2}{|c|}{166,2} & 1000 \\
\hline
\end{tabular}

Як антропогенний об'єкт досліджень було обрано діючий відвал шахти «Луганська» (рис. 16). Відвал плаский, не горить. Його висота дорівнює 92 м, площа основи - 18 га; об'єм - 12,4 млн м³ , кут відкосу $37^{\circ}$. Дата пуску відвалу в експлуатацію - 1975 p.
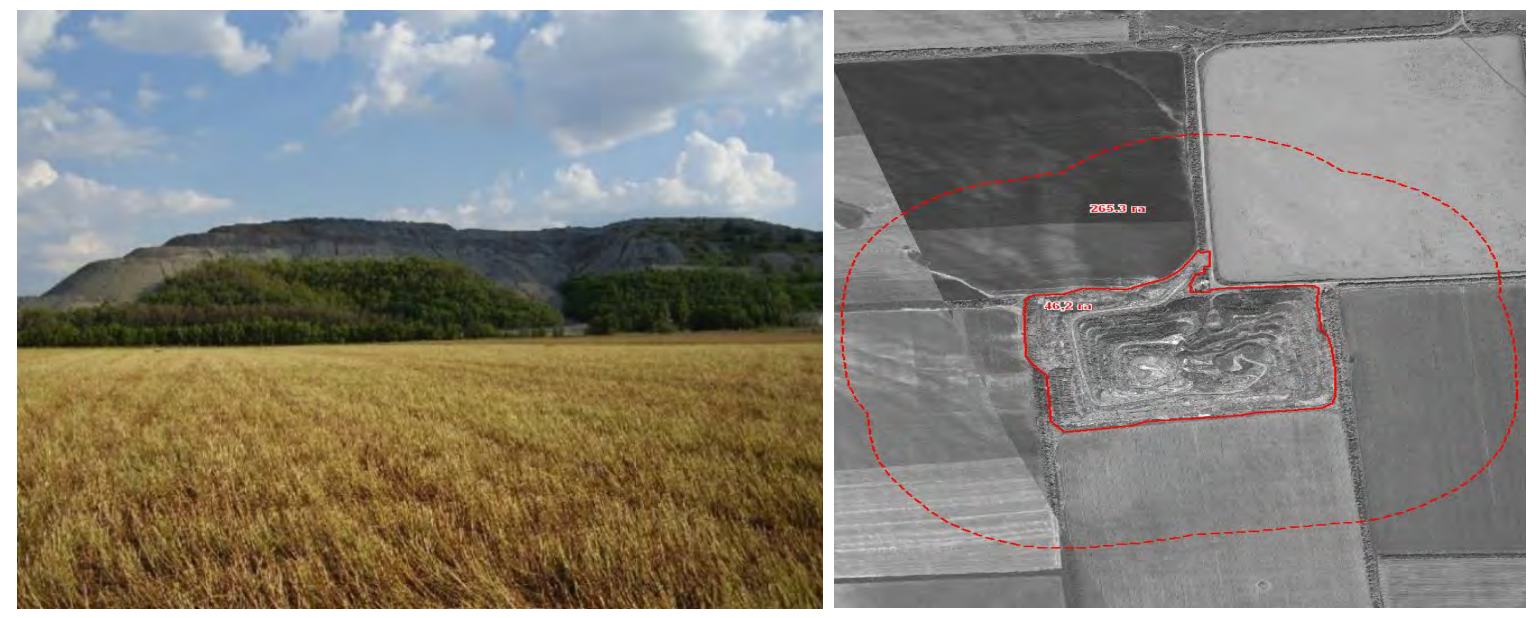

Рис. 16. Космічний знімок породного відвалу шахти «Луганська»

Відвальна порода досліджувалася на спектрометричній установці «РИТМ-С». Наочний вид отриманих спектрів ПРН представлено на рис. 17 , а протокол обробки - у табл. $17^{28}$.

Результати досліджень підтвердили присутність торію у відвальній породі вугільних шахт. Виявлено гамма-лінію природного радіонукліда ${ }^{232}$ Th зі значеннями активності 77,3 Бк і питомої активності 64,4 Бк/кг. У відвальній породі шахти «Луганська» виявлено вісмут (у т. ч. радіоактивний) (рис. 18).

\footnotetext{
${ }^{28}$ Там само.
} 

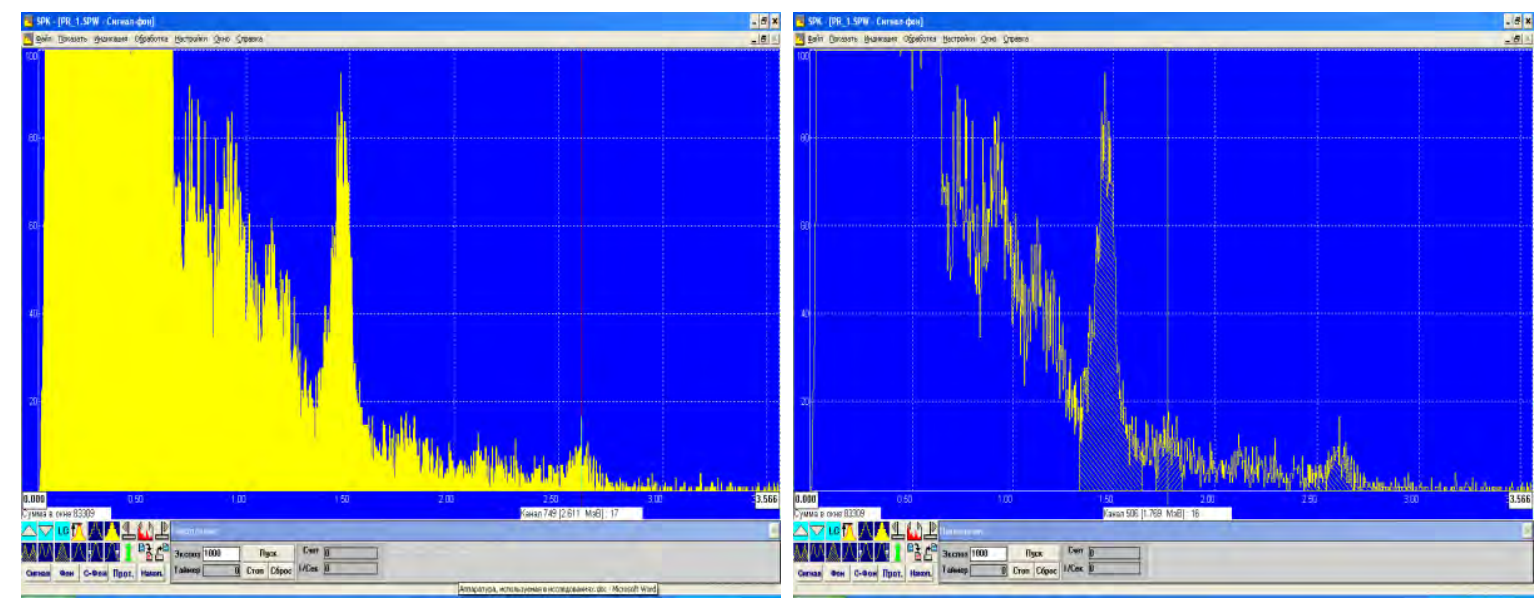

Рис. 17. Пік ${ }^{232} \mathrm{Th}$ i локалізація трьох піків ${ }^{232} \mathrm{Th},{ }^{40} \mathrm{~K} \mathrm{i}{ }^{226} \mathrm{Ra}$ на спектрі

Таблиця 17

Протокол обробки спектра гамма-випромінювання проб породи відвалу шахти «Луганська»

\begin{tabular}{|c|c|c|c|c|c|c|}
\hline \multirow{2}{*}{$\begin{array}{l}\text { № } \\
\Pi / \Pi\end{array}$} & \multirow{2}{*}{ Нуклід } & \multicolumn{2}{|c|}{ Активність } & \multicolumn{2}{|c|}{ Питома активність } & \multirow{2}{*}{$\begin{array}{c}\text { Похибка } \\
\text { активності, \% }\end{array}$} \\
\hline & & Бк & мкКи & Бк/кг & мкКи/кг & \\
\hline 1 & ${ }^{232} \mathrm{Th}$ & 77,3 & 0,0021 & 64,4 & 0,0017 & 10,4 \\
\hline 2 & ${ }^{226} \mathrm{Ra}$ & 203,6 & 0,0055 & 169,6 & 0,0046 & 12,2 \\
\hline 3 & ${ }^{40} \mathrm{~K}$ & 1270,9 & 0,0343 & 1059,1 & 0,0286 & 17,7 \\
\hline \multicolumn{2}{|c|}{$\begin{array}{c}\text { Обєм проби, } \\
\text { см }^{3}\end{array}$} & \multicolumn{2}{|c|}{$\begin{array}{c}\text { Маса проби, } \\
\text { кг }\end{array}$} & \multicolumn{2}{|c|}{$\begin{array}{c}\text { Питома ефективна } \\
\text { активність, Бк/кг }\end{array}$} & $\begin{array}{c}\text { Час виміру } \\
\text { (експозиція), с }\end{array}$ \\
\hline \multicolumn{2}{|c|}{1000} & \multicolumn{2}{|c|}{1,2} & \multicolumn{2}{|c|}{344} & 1200 \\
\hline
\end{tabular}

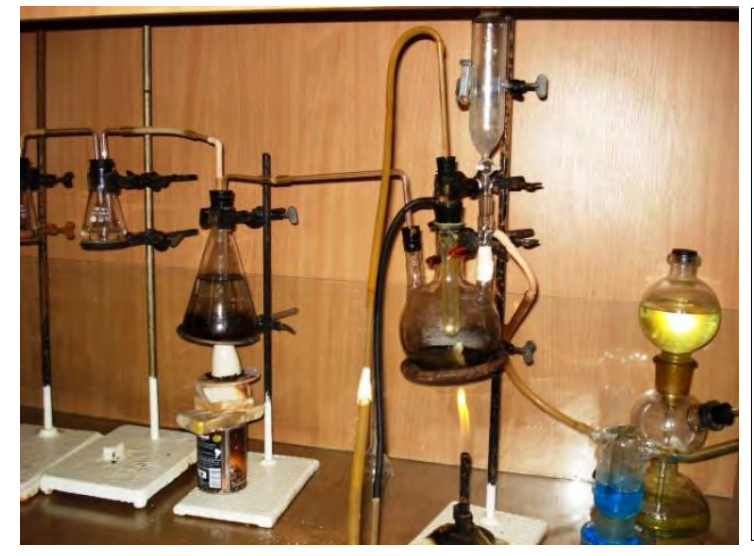

Вміст вісмуту, мг/кг

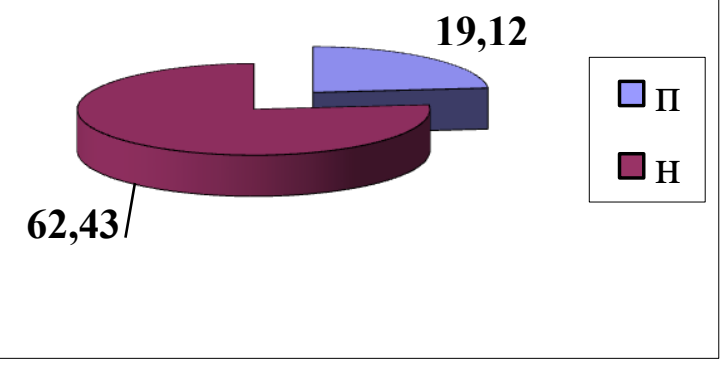

Рис. 18. Виявлення вісмуту у відвальній породі (П - перегоріла, Н - неперегоріла)

Порівняння даних табл. 17 і табл. 16 свідчить про те, що виявлена при аналізі відвальної породи вугільної шахти Донбасу гамма-лінія природного радіонукліду ${ }^{232} \mathrm{Th} \epsilon$ близькою за значеннями активності та 
питомої активності до лінії, виявленої при аналізі магматичної породи на прикладі вулкану Кара-Даг (69,3 Бк та 68,8 Бк/кг).

У сірчанокислих природних і антропогенних ладшафтах теоретично можливим $\epsilon$ поділ торію. Джерелом нейтронів для реакції поділу можуть виступати грози. Гроза - плазма (газ, іонізований у певному обсязі) передає нейтрони за допомогою електричних сил.

Нижче представлено опис грозових явищ у сірчанокислих ландшафтах природного (вулкани) й антропогенного (відвали вугільних шахт) походження (табл. 18 і 19).

Таблиця 18

Кількісні показники гроз (день, вечір), що спостерігалися в районі стародавнього вулкану Кара-Даг (1997-2016 рр.) ${ }^{29}$

\begin{tabular}{|c|c|c|c|c|c|c|c|c|c|c|c|c|c|c|c|c|c|c|c|c|c|c|}
\hline \multirow[b]{2}{*}{ Місяці } & \multicolumn{21}{|c|}{ Роки } & \multirow[b]{2}{*}{ Усього } \\
\hline & $\hat{\sigma}$ & $\stackrel{\infty}{\stackrel{2}{2}}$ & ڤे & 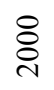 & ్ㅇㅇ & ঠి & @̊ & ষ্ণ & ஜ̊ & ஓे & $\hat{\overbrace{}}$ & 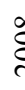 & & & $\stackrel{\circ}{\stackrel{2}{ }}$ & $\overrightarrow{\bar{\sigma}}$ & $\stackrel{ }{\stackrel{ }{\nu}}$ & $\stackrel{m}{\stackrel{\sim}{2}}$ & $\underset{\sim}{\stackrel{\Xi}{\sim}}$ & $\frac{n}{2}$ & $\underset{\sim}{\stackrel{0}{\circ}}$ & \\
\hline Січень & & & & & $-/ 1$ & & & & & & & & & & & & & & & & & $-/ 1$ \\
\hline \multicolumn{23}{|l|}{ Лютий } \\
\hline Березень & & & & & $1 /-$ & & & & & & & & & & & & & & & & & $1 /-$ \\
\hline \multicolumn{23}{|l|}{ Квітень } \\
\hline Травень & & $1 /-$ & & & & & & & $1 /-$ & & & & & & $2 /-$ & & & & & & $4 / 1$ & $8 / 1$ \\
\hline Червень & $-/ 1$ & $3 /-$ & $4 / 1$ & $-/ 2$ & $1 /-$ & $1 /-$ & & $4 /-$ & $4 / 2$ & $1 / 1$ & & & & & $1 /-$ & $2 /-$ & $1 /-$ & $3 /-$ & $3 / 1$ & $2 /-$ & $1 /-$ & $31 / 8$ \\
\hline Липень & $1 /-$ & & $2 /-$ & & & $2 /-$ & & & $1 /-$ & $1 /-$ & & & & - & $4 / 1$ & & $2 / 2$ & $1 /-$ & $1 /-$ & & $1 / 1$ & $18 / 4$ \\
\hline Серпень & $3 / 1$ & & $3 /-$ & $-/ 1$ & & $3 / 1$ & $1 /-$ & $2 / 2$ & $2 / 2$ & $1 /-$ & & & & & & $1 / 2$ & & $1 /-$ & $2 /-$ & & $3 / 2$ & $24 / 11$ \\
\hline Вересень & $1 /-$ & & $1 /-$ & $1 /-$ & & & & $1 /-$ & $1 / 2$ & & & & & & & & & & & & & $7 / 4$ \\
\hline Жовтень & $1 /-$ & & & & & & & & & & & & & & & & & & & & & $1 /-$ \\
\hline Листопад & & & & & & & & & & $1 /-$ & & & & & & & & & & & & $1 /-$ \\
\hline \multicolumn{23}{|l|}{ Грудень } \\
\hline $\begin{array}{l}\text { За рік } \\
\text { день/вечір }\end{array}$ & $6 / 2$ & $4 /-$ & $10 / 1$ & $1 / 3$ & $2 / 1$ & $6 / 1$ & $1 /-$ & $7 / 2$ & $9 / 6$ & $4 / 1$ & & & & & $7 / 2$ & $3 / 2$ & $3 / 2$ & $5 /-$ & $6 / 1$ & $2 /-$ & $9 / 2$ & \\
\hline $\begin{array}{l}\text { За рік } \\
\text { усього }\end{array}$ & 8 & 4 & 11 & 4 & 3 & 7 & 1 & 9 & 15 & 5 & & & & & 9 & 5 & 5 & 5 & 7 & 2 & 11 & \\
\hline
\end{tabular}

Аналіз грозових явищ у районі розташування стародавнього вулкану Кара-Даг дозволив виявити деякі закономірності й аномалії:

1)Нове, третє тисячоліття в районі розташування стародавнього вулкану почалося із грози, яка більше ніколи (за період із 1997 по 2016 рр.) взимку не спостерігалася. Гроза сталася 19 січня 2001 р. за температури $-1{ }^{\circ} \mathrm{C}$, тоді як зазвичай грози в цьому районі спостерігалися тільки за температури понад $+10^{\circ} \mathrm{C}$.

2) Аналіз даних за період із 1997 по 2016 рр. показав, що кількість гроз за рік на території стародавнього вулкану Кара-Даг коливається в межах від 1 до 14, при середньому значенні грозових явищ 7 за один рік.

3) За 20 років максимальна кількість гроз спостерігалася у червні, липні, серпні (відповідно 39, 22, 35).

\footnotetext{
${ }^{29}$ Там само.
} 
4) Після малої кількості гроз за рік (1-3) у наступному році відбувається їх різке збільшення.

5) Зі 119 випадків грозових явищ, що спостерігалися в досліджуваний період, 96\% гроз відбувалися за атмосферного тиску від 750 до 760 мм рт. ст. на рівні моря; інші 4\% гроз - за 760-770 мм рт. ст.

6) Зі 119 випадків грозових явищ, які спостерігалися за досліджуваний період, 94\% гроз відбувалося за температури від +15 до $+30^{\circ} \mathrm{C} ; 3 \%$ гроз за температури від +10 до $+15^{\circ} \mathrm{C}$; інші (близько $2 \%$ ) - за температури $+32^{\circ} \mathrm{C}$.

7) Майже не виявлено жодної залежності грозових явищ від напрямку вітру, за винятком того, що більша кількість гроз спостерігалася при вітрах основних румбів: Пн, Пд, Зх, Сх.

8) 3 усіх виявлених випадків гроз 80\% спостерігалися за швидкості вітру від 1 до 3 м/с, 13\% - за швидкості вітру від 4 до 5 м/с, 5\% - за швидкості 6-9 м/с і решта 2\% - при штилі.

9) Близько 59\% гроз відбувалося за похмурої погоди; 32\% - за хмарної, 9\% - за малохмарної; одна гроза спостерігалася за ясної погоди.

У табл. 19 представлені кількісні показники гроз в антропогенних сірчанокислих териконових ландшафтах Донбасу.

Таблиця 19

Кількісні показники гроз, що спостерігалися у районі розташування відвалу шахти «Луганська» (1997-2016 рр.) ${ }^{30}$

\begin{tabular}{|c|c|c|c|c|c|c|c|c|c|c|c|c|c|c|c|c|c|c|c|c|}
\hline \multirow[b]{2}{*}{ Місяці } & \multicolumn{20}{|c|}{ Роки } \\
\hline & $\hat{a}$ & $\begin{array}{l}\infty \\
\stackrel{2}{a}\end{array}$ & & 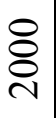 & $\overline{\mathrm{\delta}}$ & ঠి & ֻ̊ & 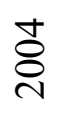 & ஜ̊ & ঠ̊ & 용 & 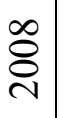 & ஓి & $\stackrel{\circ}{\stackrel{\circ}{\curvearrowright}}$ & $\overline{\bar{\delta}}$ & $\frac{\sim}{\stackrel{\sim}{~}}$ & $\frac{m}{\delta}$ & $\stackrel{\nabla}{\Xi}$ & $\frac{n}{\delta}$ & $\frac{0}{\stackrel{0}{\sigma}}$ \\
\hline Квітень & & & 1 & 2 & 2 & 1 & 1 & & & 1 & & & & 2 & & 2 & & & & 1 \\
\hline Травень & & & & 1 & 1 & 4 & & 1 & & 1 & 2 & 4 & 3 & 4 & & 2 & 3 & 7 & 1 & \\
\hline Червень & 4 & 4 & 4 & 1 & 6 & & 3 & & 4 & 8 & 6 & 3 & 2 & 3 & 6 & 3 & 2 & 1 & 2 & \\
\hline Липень & 7 & 1 & 6 & 2 & 3 & 9 & 7 & & & 2 & 2 & 4 & 5 & 4 & 2 & 2 & 4 & 1 & & 1 \\
\hline Серпень & 1 & 1 & 1 & 1 & & 2 & 3 & 1 & 1 & 1 & 1 & 1 & 1 & & 2 & 1 & 4 & & 1 & 1 \\
\hline Вересень & 1 & & & 1 & 1 & 4 & & 2 & 1 & 1 & 1 & & 1 & 1 & & & 2 & & & \\
\hline Жовтень & & & & & & & 1 & & & & & & & & & & & & & \\
\hline Листопад & & & & & & & & & & & & 1 & & & & & & & & \\
\hline
\end{tabular}

Аналіз даних табл. 19 за період 1997-2015 рр. показав, що кількість гроз за рік на досліджуваній території коливається від 4 до 20 за середньої кількості грозових явищ 11. Дані грозових явищ однорідні, що підтверджується перевіркою за критерієм Стьюдента, і відповідають як

\footnotetext{
30 Там само.
} 
рідкісні явища закону Пуассона, що підтверджується критерієм $\chi$-квадрат Пірсона ${ }^{31}$.

Встановлено, що 31997 по 2015 рр. найбільше грозових явищ спостерігалося у 2000 р. за період із червня по серпень.

Вулкан - «вмістилище-відстійник» магматичного розплаву солей із розчиненим у них торієм - щомиті готовий до реакції поділу останнього в разі впливу на нього нейтронів грози. Місця виходу на поверхню сульфідних руд - це місця (у вологих тропіках, степу і пустелі), на яких окислення сульфідів призводить до утворення сірчаної кислоти, «розкриття» торію, утворення його гідроксиду у вигляді седиментів, розчинення торію в розплавах солей при взаємодії з нейтронами грози.

Кульова блискавка - болід, який утворюється внаслідок ядерної реакції торію, спровокованої лінійною блискавкою, і $\epsilon$ згустком продукту розпаду торію - газоподібним ${ }^{220} \mathrm{Rn}$ (тороном) із тривалістю життя 55 с (тривалість життя кульової блискавки така сама), котрий виділяється внаслідок еманації із седиментів гідроксиду (твердої речовини материнських елементів) для встановлення радіоактивної рівноваги $^{32}$.

На рис. 18 представлена запропонована умовна схема ядерної реакції, що відбувається при взаємодії нейтронів грози з магматичним розплавом солей торію. Така сама ядерна реакція може відбуватися на ділянках окислення сульфідних руд із «розкритим» сірчаною кислотою торієм, який переходить при підвищенні кислотності водного розчину в седимент гідроксиду торію. Наявні на ділянках окислення сульфідних руд солі за високих температур розплавляються і розчиняють металевий торій. Тобто грози як джерела нейтронів «мають справу» або з готовим розплавом солей у магмі, або із седиментом гідроксиду торію, що розчиняється в розплавах солей, які утворюються, як і седимент, при високотемпературному окисленні сульфідних руд. При взаємодії «розкритого» торію 3 нейтронами грози і ядерному розщепленні всі «металеві» дочірні елементи переходять із кристалічної решітки в розплави солей. Тільки ${ }^{220} \mathrm{Rn}$ (торон) із тривалістю життя 55 с у вигляді газоподібного згустку (кульової блискавки) залишає межі об’єму іонізації (плазми) ${ }^{33}$.

Виходячи 3 рис. 19, на першому етапі, коли спостерігається 0,1 мс імпульс, здійснюється передача нейтронів, необхідних для початку ядерного синтезу торію. Реакція поділу починається. Відбувається викид енергії зі свіченням, нагрів термостійкого плазмового тіла і його розширення.

\footnotetext{
${ }^{31}$ Там само.

32 Там само.

${ }^{33}$ Там само.
} 
1. Іпульс 0,1 мс, передача нейтронів торію, початок ядерної реакції ${ }^{\llcorner\Delta L} \mathrm{Th}+\mathrm{n} \rightarrow$ ${ }^{233} \mathrm{Th} \rightarrow{ }^{233} \mathrm{~Pa}+\mathrm{e}$.

2. Викид енергії зі свіченням, нагрів плазмового тіла i його розширення, уповільнення реакції.

3. Пауза 10-50 мс, зниження температури плазмового тіла і його звуження.

1. Імпульс 0,1 мс, передача нейтронів торію, продовження ядерної реакції.

2. Викид енергії зі свіченням, нагрів плазмового тіла i його розширення, уповільнення реакції.

3. Пауза 10-50 мс, зниження температури плазмового тіла і його звуження.

1. Імпульс 0,1 мс, передача нейтронів торію, продовження ядерної реакції.

2. Виброс енергії зі свіченням, нагрів плазмового тіла i його розширення, припинення ядерної реакції.

3. Повна рекомбінація.

\section{Рис. 19. Умовна схема ядерної реакції, що відбувається при взаємодії нейтронів грози з магматичним розплавом солей торію}

При розширенні плазмового тіла відбувається зниження концентрації торію і нейтронів. Це призводить до уповільнення ядерної реакції та паузи у 10-50 мс для зниження температури плазмового тіла і його звуження. Внаслідок звуження плазмового тіла відновлюється первинний об'єм плазми та концентрація торію і нейтронів. Наступний імпульс сприяе передачі нейтронів торію і продовженню ядерної реакції. Лавина імпульсів сприяє повному проходженню ядерної реакції торію. Рекомбінація (повернення газу у стан, у якому він перебував до іонізації) не здійснюватиметься доти, поки не закінчиться повністю розщеплення торію. Уповільнення настання рекомбінації відбувається внаслідок кластеризації (гідратації газових іонів у хмарі). Ядерна реакція відбувається тільки в межах об'єму іонізації, тобто в межах поширення плазмового тіла ${ }^{34}$.

Наочний вид взаємодії діючого плаского відвалу шахти «Луганська» із хмарним утворенням представлено на рис. 20.

\section{ВИСНОВКИ}

Пірит, що міститься у всіх видах вугілля Донбасу, при розробці пласта або потраплянні разом із відвальної породою териконів на поверхню вступає у реакцію із киснем повітря. Окислюючись, він сприяє утворенню сірчанокислого класу підземних і поверхневих вод, грунтів, кори вивітрювання, тобто відбувається трансформація природних ландшафтів в антропогенні сірчанокислі. Природні ж сірчанокислі ландшафти виникають у вулканічних районах, а також у місцях виходу на поверхню сульфідних руд.

\footnotetext{
${ }^{34}$ Там само.
} 


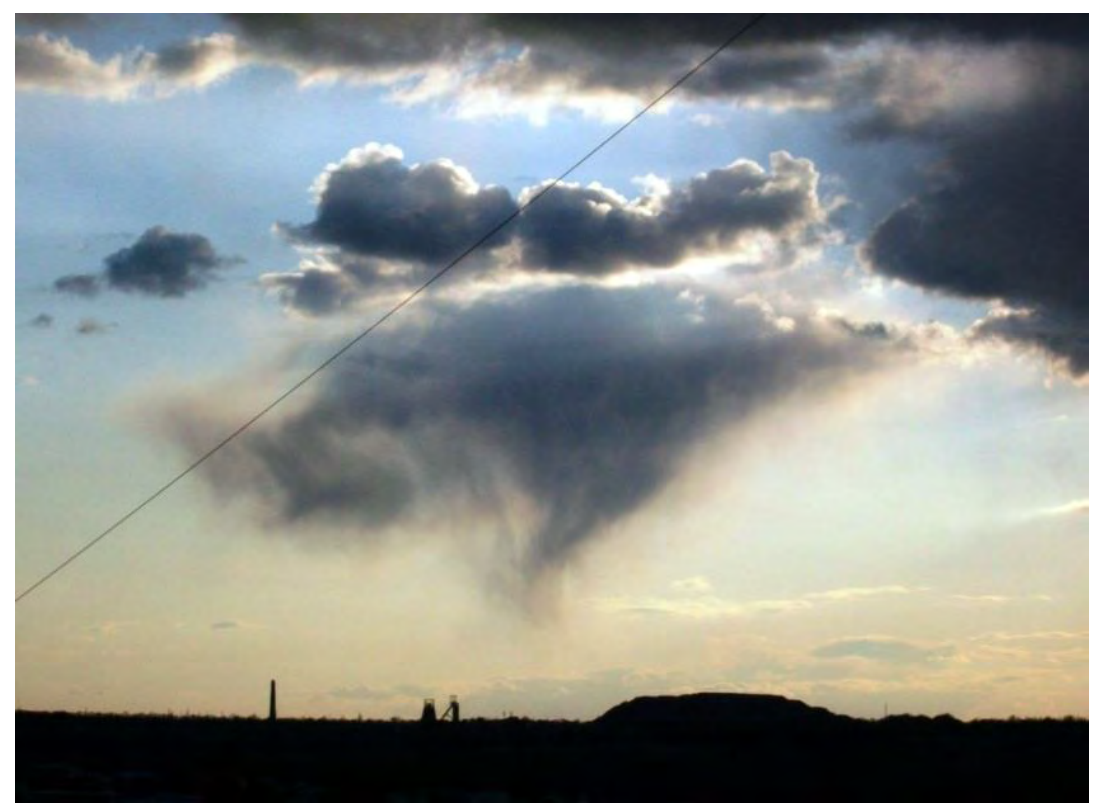

\section{Рис. 20. Взаємодія плаского відвалу шахти «Луганська» із хмарним утворенням}

Спостерігається зв'язок «Тихоокеанського вогняного кільця» (природних сірчанокислих ландшафтів острівних вулканів) із антициклонами Північної півкулі Землі. Розташування зимових антициклонів Північної півкулі над континентами, наявність снігового покриву, присутність карбонату кальцію в ілювіальному горизонті грунтів пов'язані між собою. Антициклональна діяльність у Північній півкулі Землі теоретично аналогічна етапам отримання «водяного газу» (Watergas або Wassergas) і гіпотетично може істотно впливати на здоров'я населення Землі.

Глобальні катастрофічні атмосферні явища пов'язані з видобутком вугілля, тобто із сірчанокислими ландшафтами антропогенного походження.

Висунуто припущення, що на ділянках розташування розроблюваних вугільних родовищ, де немає вічної мерзлоти, ядерний поділ торію викликає карстування вапняків, а на територіях із товщею непробивної вічної мерзлоти - вибух болідів (появу псевдометеоритів).

Результати досліджень підтвердили присутність торію як у відвальній породі типових вугільних шахт (виявлена гамма-лінія природного радіонукліда ${ }^{232} \mathrm{Th}$ зі значеннями активності 77,3 Бк і питомої активності 64,4 Бк/кг), так і в геологічних утвореннях стародавнього вулкану КараДаг (гамма-лінія природного радіонукліда ${ }^{232}$ Th 3 активністю 69,3 Бк та питомою активністю 68,8 Бк/кг). Тобто в сірчанокислих природних і антропогенних ландшафтах теоретично можливим $\epsilon$ поділ торію. Джерелом нейтронів для реакції поділу можуть виступати грози. 


\section{АНОТАЦІЯ}

Природні сірчанокислі ландшафти формуються у вулканічних районах і в місцях виходу на поверхню сульфідних руд, антропогенні на територіях видобутку вугілля. Спостерігається тісний зв'язок природних сірчанокислих ландшафтів острівних вулканів («Тихоокеанського вогняного кільця») 3 антициклонами Північної півкулі Землі. Глобальні катастрофічні атмосферні явища (псевдометеорити) пов'язані 3 видобутком вугілля, тобто із сірчанокислими ландшафтами антропогенного походження. $\mathrm{y}$ сірчанокислих природних i антропогенних ландшафтах теоретично можливим $є$ поділ торію.

\section{ЛІТЕРАТУРА}

1. Перельман А.И. Биокосные системы Земли. Москва : Наука, 1977. $160 \mathrm{c}$.

2. Хромов С.П., Петросянц М.А. Метеорология и климатология : учебник. Москва : Изд-во МГУ, 2001. 528 с.

3. Гончарова Л.Д., Серга Е.М., Школьний Є.П Клімат і загальна циркуляція атмосфери : навчальний посібник. Київ : КНТ, 2005. 251 с.

4. Вулканы и вулканология. URL: http:/geo.web.ru/db/volcano/ active volcano.html.

5. Инфоурок. URL: https://fs00.infourok.ru/images/doc/225/29589/1/ img4.jpg.

6. Рощин А.Н. Сам себе синоптик. Киев : Рад. школа, 1983. 206 с.

7. Лубков А.С., Воскресенская Е.Н., Марчукова О.В. Пространственновременная классификация явлений Эль-Ниньо. Maтер. конф. «Окружающая среда и человек». Ростов-на-Дону : Изд-во ЮНЦ РАН, 2016. C. $110-112$.

8. Маслова В.Н. Циклоническая активность в ЧерноморскоСредиземно-морском регионе : автореф. дис. ... канд. геогр. наук : 11.00.09. Севастополь, 2012. 20 с.

9. Горелов А.А. Концепции современного естествознания : учебное пособие. Москва : ООО «Издательство АСТ», 2003. 380 с.

10. Зубова Л.Г. Торий в природе и в сернокислых ландшафтах (научные факты и гипотезы) : монография. Луганск : Изд-во «Ноулидж», 2017. $72 \mathrm{c}$.

11. Терриконы : монография / Л.Г. Зубова, А.Р. Зубов, А.А. Зубов, А.В. Харламова, С.Г. Воробьев и др. Луганск : Изд-во Ноулидж, 2015. $716 \mathrm{c}$.

12. Смирный М.Ф., Зубова Л.Г., Зубов А.Р. Экологическая безопасность терриконовых ландшафтов Донбасса : монография. Луганск : Изд-во ВНУ им. В. Даля, 2006. 232 с. 
13. Зубова Л.Г., Зубов О.Р. Гідроекологічні проблеми Донбасу. Луганськ : Вид-во ЛНУ ім. В. Даля, 2008. 100 с.

14. Зубова Л.Г. Глобальные катастрофические явления в угледобывающей промышленности разных стран. Уголь Украины. 2018. № 3. С. 39-47.

15. Гвоздецкий Н.А. Карст. Москва : Мысль, 1981. 214 с.

Information about authors:

Zubova L. G.,

Doctor of Technical Sciences, Professor

Zubov O. R.,

Doctor of Agricultural Sciences, Professor

Zubov A. O.,

Candidate of Technical Sciences, Doctoral Candidate Institute of Agroecology and Environmental Management of the National Academy of Agrarian Sciences of Ukraine 12, Metrological str., Kyiv, 03143, Ukraine 